\title{
A new species of Eptesicus (Mammalia: Chiroptera: Vespertilionidae), from the sub-Andean Forest of Santa Cruz, Bolivia
}

\author{
Luis H. Acosta S. ${ }^{*}$, José luis Poma-Urey ${ }^{1}$, Paula A. Ossa-López ${ }^{2,3}$, Fredy A. Rivera-Páez ${ }^{3}$ and Héctor E. Ramírez-Chaves 3,4 \\ ${ }^{1}$ Museo de Historia Natural Noel Kempff Mercado, Universidad Autónoma Gabriel René Moreno, Avenida Irala 565, Casilla postal \\ 2489. Santa Cruz de la Sierra-Bolivia. Email:I.jubatus096@gmail.com (LHAS), jose luipoma@hotmail.com (JLPU). \\ 2 Doctorado en Ciencias, Biología, Facultad de Ciencias Exactas y Naturales, Universidad de Caldas, Calle 65 No. 26-10, 170004, \\ Manizales. Caldas, Colombia. Email: paula.ossa@ucaldas.edu.co (PAOL). \\ ${ }^{3}$ Grupo de Investigación en Genética, Biodiversidad y Manejo de Ecosistemas (GEBIOME), Departamento de Ciencias Biológicas, \\ Facultad de Ciencias Exactas y Naturales, Universidad de Caldas, Calle 65 № 26-10, 170004, Manizales. Caldas, Colombia. Email: \\ fredy.rivera@ucaldas.edu.co (FARP). \\ ${ }^{4}$ Centro de Museos, Museo de Historia Natural, Universidad de Caldas, Carrera 23 \#59-21, Manizales. Caldas, Colombia. Email: \\ hector.ramirez@ucaldas.edu.co (HERC). \\ *Corresponding author
}

Bats of genus Eptesicus are represented in South America by nine species of short-eared taxa (subgenus Eptesicus), and 10 species of long-eared species (subgenus Histiotus). Here we describe a new species of short-eared Eptesicus based on 19 specimens collected in the sub-Andean Bolivian-Tucumanian forest of Santa Cruz, between 1800-2020 masl. For this, we include morphological, morphometric, and molecular comparisons; we use principal component, discriminant function and mitochondrial genes (cytochrome-b, cytochrome c oxidase subunit I, and nicotinamide adenine dinucleotide dehydrogenase) to compare the new species with other taxa of the subgenus Eptesicus from South America. The new species is distinguished from its congeners by cranial shape, body measurements, and genetic distances. Furthermore, the new species is similar in cranial morphology to Eptesicus andinus but presents a highly developed frontal preorbital process, poorly developed in other related species (i. e., E. andinus, E. furinalis, and E. brasiliensis). All males were consistently darker than females in the new species. This taxon increases to 10 the number of species of bats of the subgenus Eptesicus in South America.

Los murciélagos del género Eptesicus en Sudamérica están representados por nueve especies de murciélagos de orejas cortas (subgénero Eptesicus) y 10 especies de orejas largas (subgénero Histiotus). Describimos una nueva especie de Eptesicus de orejas cortas, con base en 19 especímenes, que fueron colectados en el Bosque Boliviano-Tucumano del subandino de Santa Cruz, entre los 1800-2020 msnm. Para esto, incluimos comparaciones morfológicas, morfométricas y moleculares; utilizamos los análisis de componente principal, función discriminante y genes mitocondriales (citocromo-b, citocromo c oxidasa subunidad I y nicotinamida adenina dinucleótido deshidrogenasa) para comparar la nueva especie con otros taxones del subgénero Eptesicus de Sudamérica. La nueva especie se distingue de sus congéneres por su forma craneal, medidas corporales, dicromatismo sexual notable y las distancias genéticas. Además, la nueva especie es similar en la morfología craneal con Eptesicus andinus, pero esta presenta un proceso preorbital frontal muy desarrollado el cual es pobremente desarrollado en las especies relacionadas (i. e., E. andinus, E. furinalis y E. brasiliensis). Todos los machos en la nueva especie fueron evidentemente más oscuros que las hembras. Este nuevo taxón aumenta a 10 el número de las especies del subgénero Eptesicus en Sudamérica.

Keywords: Andes; cryptic diversity; cyt- $b$; COI; Histiotus; morphology; ND1.

๑c 2021 Asociación Mexicana de Mastozoología, www.mastozoologiamexicana.org

\section{Introduction}

The genus Eptesicus Rafinesque, 1820 in South America comprises 19 species. These 19 species are grouped into two subgenera. The subgenus Eptesicus includes nine species and several subspecies (Miranda et al. 2006; Davis and Gardner 2008; Díaz et al. 2016; Sánchez et al. 2019): Eptesicus andinus Allen, 1914 (monotypic), Eptesicus brasiliensis (Desmarest, 1819; with four subspecies), Eptesicus chiriquinus Thomas, 1920 (monotypic), Eptesicus diminutus Osgood, 1915 (with two subspecies), Eptesicus furinalis (d'Orbigny and Gervais, 1847; with two subspecies), Eptesicus fuscus (Palisot de Beauvois, 1796; one subspecies), Eptesicus innoxius (P. Gervais, 1841; monotypic), Eptesicus taddeii Miranda, Bernardi and Passos 2006 (monotypic), and Eptesicus ulapesensis Sánchez, Montani, Tomasco, Díaz and Barquez 2019 (monotypic). The subgenus Histiotus endemic to South America includes the other 10 species (Rodríguez-Posada et al. 2021). Histiotus has been considered by some authors as a subgenus of Eptesicus (Hoofer and Van Den Bussche 2003; Giménez et al. 2019; Simmons and Cirranello 2020), but this suggestion has not been followed by other authors (see Burgin et al. 2018; Moratelli et al. 2019; Barquez and Díaz 2020). Historically, Neotropical bats of the subgenus Eptesicus have been defined as species complexes based on fur variability. For example, Davis (1966) identified three long-haired species: $E$. andinus with two subspecies (E. inca and E. chiriquinus), E. montosus with two subspecies (E. montosus and E. chiralensis), and E. fuscus (monotypic). However, Simmons and Voss (1998) reviewed the holotypes of $E$. andinus and $E$. chiralensis and topotypic 
specimens of $E$. inca and $E$. chiriquinus, concluding that $E$. chiralensis and $E$. andinus are conspecifics and similarly, $E$. inca and $E$. chiriquinus are also conspecific with $E$. chiriquinus having priority over E. inca. Simmons and Voss (1998) suggested that $E$. andinus and $E$. chiriquinus can be differentiated by skull shape and the arrangement of the sagittal and nuchal ridges, as well as differences in size (E. chiriquinus tends to be larger than $E$. andinus).

Five species of the subgenus Eptesicus currently occur in Bolivia: E. andinus, E. brasiliensis, E. chiriquinus, E. diminutus, and E. furinalis (Anderson 1997; Siles 2007; VargasEspinoza 2007; Aguirre et al. 2010, 2019; Poma-Urey et al. 2019); being one of the countries with the highest diversity of the subgenus in South America. Despite that, there are several, information gaps related to the distribution and richness of the genus remain (Poma-Urey et al. 2019). Here, we describe a new species of the subgenus Eptesicus based on 19 specimens collected in the sub-Andean BolivianTucumanian forest of Santa Cruz, and by comparisons with specimens from other localities of South America. The new species is morphologically similar to $E$. andinus but can be differentiated from $E$. andinus and its congeners by genetic distances, discrete morphological and morphometric traits.

\section{Material and Methods}

A total of 19 specimens of bats of subgenus Eptesicus were collected during field trips between 2007 and 2013 in two localities in the Province of Florida, Santa Cruz Department, Bolivia (Figure 1). To assess their specific identity, 131 specimens belonging to five species of Eptesicus with confirmed presence in Bolivia were also examined: E. andinus $(n=39)$, E. brasiliensis $(n=5)$, E. chiriquinus $(n=21)$, E. diminutus $(n=$ $10)$, and Eptesicus furinalis $(n=56)$. The specimens reviewed are housed at the following institutions: American Museum of Natural History, New York, USA (AMNH); British Museum Natural History, London, England $(\mathrm{BMNH})$; Colección de Mamíferos Lillo, Tucumán, Argentina (CML); The Field Museum of Natural History, Chicago, USA (FMNH); the Instituto de Ciencias Naturales, Universidad Nacional de Colombia, Bogotá, Colombia (ICN); Noel Kempff Mercado Natural History Museum, Santa Cruz, Bolivia (MHNNKM); Museo de Historia Natural Universidad del Cauca, Popayán, Colombia (MHNUC); Museo de Historia Natural, Universidad de Caldas, Manizales, Colombia (MHN-UCa); Museo Universidad Distrital Francisco José de Caldas, Bogotá, Colombia (MUD); Colección Teriológica Universidad de Antioquia, Medellín, Colombia (CTUA); Colección Mastozoológica Universidad del Valle, Cali, Colombia (UV), and the National Museum of Natural History, Washington, DC., USA (USNM; Appendix 1).

Several external, and cranial characters described in the literature (Simmons and Voss 1998; Davis and Gardner 2008; Díaz et al. 2016) were analysed in all the specimens reviewed, including the development of the sagittal and lambdoidal ridges, and the length and colour of the coat hairs (according to Ridgway 1912), and compared with the information provided in the literature (e. g., Davis 1966).
Morphometric analysis. Nineteen cranio-dental measurements from 149 specimens were explored. These measurements included: greatest length of the skull (GLS), condylo-canine length $(\mathrm{CCL})$, basicraneal length $(\mathrm{BL})$, palatal length (PAL), postorbital constriction (POC), braincase height $(\mathrm{BCH})$, braincase breadth $(\mathrm{BCB})$, mastoid breadth $(\mathrm{MB})$, zygomatic breadth (ZB), interorbital breadth (IOB), breadth across canines $(C-C)$, breadth across upper molars (M3-M3), maxillary toothrow length (C-M3), incisive lengthM3 (I-M3), upper molariforms length (P-M3), lower caninem3 length (c-m3), lower molariforms length ( $p-m 3)$, mandibular length (MAL), mandibular height $(\mathrm{MH}$; Simmons and Voss 1998; Ramírez-Chaves 2008). We also took seven external measurements (the first two from labels) including: total length (LT), length of tail (TL), length of hind foot $(\mathrm{LF})$, length of ear (EL), length of forearm (FA), and two from the hairs: length of dorsal hair (PD) and length of ventral hair (PV). The cranio-dental measurements were taken with a 0.01 precision digital calliper, and then Log transformed for further normalization and analyses. To show the main measurements that separate the species into different groups, the data of the first two principal main components (PCA) were selected. To define the variability between the groups provided by the first two main components, a Discriminant Function Analysis (DFA; Brown and Wicker 2000) was performed, considering the first two DFAs. For both the PCA and DFA analyses, due to completeness only 14 cranio-dental measurements were used (GLS, BCH, BL, PAL, P-M3, MB, M3-M3, C-C, I-M3, C-M3, CCL, IOB, POC, BCB), and the analyses were calculated using the software PAST ver-



Figure 1. Collecting sites for Eptesicus langeri sp. nov. in South America. Municipalities of Samaipata and Pampagrande, Province of Florida, Department of Santa Cruz, Bolivia. Agua Rica Type locality (star), Reserve Municipal El Chape (circle 1) and Agua Clarita (circle 2). 
sion 2.17c for Windows platform (Hammer et al. 2001). The PCA and DFA included four similar-sized species of Eptesicus (E. andinus, E. brasiliensis, E. chiriquinus, and E. furinalis), the holotypes of E. montosus Thomas, 1920, and E. chiralensis Anthony, 1926 (considered both junior synonyms of E. andinus), one smaller species (E. diminutus), and the 19 specimens of the Province of Florida in Bolivia. We also calculated the cranial index $(C R I=(((P O C+B C B) \times G L S) / 2)$ and the maxillary index $(\mathrm{MXI}=(((\mathrm{C}-\mathrm{C}+\mathrm{M} 3-\mathrm{M} 3) \times \mathrm{C}-\mathrm{M} 3) / 2)$ (Baud and Menu 1993).

Molecular analyses. We extracted genomic DNA from muscle tissues preserved in $96 \%$ ethanol from five specimens of Eptesicus collected in the sub-Andean BolivianTucumanian forest of Bolivia, and two $E$. andinus, one $E$. chiriquinus, and one $E$. furinalis from Colombia. DNA were extracted using Wizard ${ }^{\circledR}$ Genomic DNA Purification kit (Promega Corporation) following the manufacturer's protocol. Amplification of three mitochondrial genes was done as follows: the amplification of cytochrome-b (cyt-b) gene was performed using two pairs of primers. First pair of primers L14816: 5'-CCATCCAACATCTCAGCATGATGAAA-3' and H15173: 5'-CCCCTCAGAATGATATTTGTCCTCA-3' which amplifies $\mathrm{a} \approx 358 \mathrm{bp}$ fragment (Parson et al. 2000), and the other pair of primers LGL765F: 5'-GAAAAACCAYCGTTGTWATTCAACT-3' (Bickham et al. 1995) and LGL766R 5'-GTTTAATTAGAATYTYAGCTTTGGG-3', targeting a $\approx 1140$ bp fragment (Bickham et al. 2004). Amplification of nicotinamide adenine dinucleotide dehydrogenase (ND1) gene using primers ND1-Forward 5'-CGCCATTATATGATCAGGATGAGCC-3' and ND1-Reverse 5'-GTWGAGATRAATCATATTAT-3' which amplifies a $\approx 293-295$ bp fragment (Hamilton et al. 2015). The cytochrome c oxidase subunit I (COI) gene was amplified using the primer pair MCOIF 5'-CTGTACTTAGATTTACAGTCTAATGCC-3' and MCOIR 5'-CCAAAGCCAGGCAAAATTAAAATATA-3', which amplify a fragment of approximately 657 bp (Sánchez et al. 2019). The final amplification reaction volume was $30 \mu \mathrm{L}$, which contained 16.84 $\mu \mathrm{L}$ ultrapure water, $6 \mu \mathrm{L} 5 \mathrm{X}$ buffer, $1.8 \mu \mathrm{L} \mathrm{MgCl}$ ( $25 \mathrm{mM}), 2.4$ $\mu \mathrm{L}$ dNTP mix $(10 \mathrm{mM}), 0.36 \mu \mathrm{L}$ of each primer $(25 \mu \mathrm{M}), 1.2 \mathrm{U}$ of GoTaq Flexi DNA Polymerase (Promega), and $2 \mu \mathrm{L}$ DNA (approximately 100-150 ng of DNA).

The amplifications were performed on a Techne TCPLUS thermocycler, according to the following conditions for the $c y t-b$ and ND1 genes: initial denaturation of 3 min at $94^{\circ} \mathrm{C}$, followed by 35 cycles of $30 \mathrm{~s}$ of denaturation at $94^{\circ} \mathrm{C}, 30 \mathrm{~s}$ of annealing at variable temperature depending on markers (between $46^{\circ} \mathrm{C}$ and $50^{\circ} \mathrm{C}$ ) and $30 \mathrm{~s}$ of extension at $72^{\circ} \mathrm{C}$, and a final extension of $5 \mathrm{~min}$ at $72^{\circ} \mathrm{C}$. Initial denaturation at 95 ${ }^{\circ} \mathrm{C}$ for $5 \mathrm{~min}$, followed by 5 cycles at $94^{\circ} \mathrm{C}$ for $5 \mathrm{~min}, 46^{\circ} \mathrm{C}$ for $1 \mathrm{~min} 30 \mathrm{~s}$, and $72{ }^{\circ} \mathrm{C}$ for $1 \mathrm{~min} 30 \mathrm{~s}$, followed by 35 cycles at $94^{\circ} \mathrm{C}$ for $1 \mathrm{~min}, 53^{\circ} \mathrm{C}$ for $1 \mathrm{~min}$, and $72^{\circ} \mathrm{C}$ for $1 \mathrm{~min}$, completing the reaction with a final extension cycle at $72{ }^{\circ} \mathrm{C}$ for $5 \mathrm{~min}$, for the COI gene. The PCR products were quantified by fluorometry using a Quantus Fluorometer ${ }^{\mathrm{TM}}$ (Promega ${ }^{\oplus}$ ) with the QuantiFluor ${ }^{\circledR}$ dsDNA System (Promega ${ }^{\circledR}$ ), according to the manufacturer's protocol. PCR products were sent to Macrogen Inc. (South Korea) for purification and DNA sequencing. The sequenced fragments were evaluated and edited using Geneious Trial v8.14 (Drummond et al. 2009). To further compare sequence divergence, we downloaded sequences of closely related taxa of the subgenera Eptesicus and Histiotus available in GenBank (Appendix 1 and 7). As outgroup, we used Myotis riparius and Neoromicia guineensis (Appendix $1 \mathrm{~A}$ and B).

The sequences for each gene were aligned using ClustalW (Thompson et al. 1997), included in the program MEGA $X$ (Kumar et al. 2018). Intraspecific and interspecific nucleotide divergences were estimated with the program MEGA $\mathrm{X}$, using the Kimura 2-Parameter distance model (K2P; Kimura 1980) and 1,000 bootstrap replications. For single and concatenated sets of mitochondrial genes we selected the best-fitting models of sequence evolution, using the Akaike Information Criterion (AIC) calculated with ModelFinder (Kalyaanamoorthy et al. 2017) in PhyloSuite (Zhang et al. 2020). For the concatenated analysis, and the cyt- $b$ gene (Appendix 1) we selected the GTR+F+I+G4 substitution model. Bayesian Inference (BI) analysis was conducted with MrBayes 3.2.6 (Ronquist et al. 2012), with four parallel runs, 2,000,000 generations, in which the initial $25 \%$ of sampled data were discarded as burn-in.

Phylogenetic analyses for the ND1 and COI genes were inferred by using the Maximum Likelihood (ML) method with different evolutionary models (GTR+F+G4 for ND1, and TVM+F+R2 for COI). The ML analysis was conducted with IQ-TREE (Nguyen et al. 2015), 5,000 ultrafast bootstraps (Minh et al. 2013); as well as Shimodaira-Hasegawalike approximate likelihood-ratio test (SH-like aLRT) for branches with 1,000 replicates (Guindon et al. 2010), all included in PhyloSuite platform (Zhang et al. 2020). Finally, we used the graphical viewer of phylogenetic trees FigTree v.1.4.3 (Rambaut 2007).

\section{Results}

Based on the review of 131 specimens of Eptesicus andinus, E. brasiliensis, E. chiriquinus, E. diminutus and E. furinalis, the 19 individuals from the Province of Florida, were assigned to the andinus group based on cranial morphology, E. andinus being the most morphological similar taxon. However, the specimens from Florida (Bolivia) showed a combination of discrete morphological characteristics that were not observed in any other Eptesicus known in South America. Among these, the presence of a well-developed frontal preorbital process allowed us to separate the specimens from Florida from specimens of $E$. andinus. The first two components of the PCA and DFA (Figure 2) account for $84.9 \%$ and $84.7 \%$ of the variation in the dataset, respectively (Table 1 ). PCA 1 accounted for $78.9 \%$ of the variation, with all positive values, the highest values were given by the variables: GLS, CCL, I-M3 and C-M3. The second PCA explained $6.1 \%$ of the variation; $\mathrm{POC}, \mathrm{BCB}$ were among the variables with higher positive values, while the negative values were obtained for IOB, MB and PAL (Table 1). 
The DFA shows that specimens from Province of Florida are part of the medium-sized Eptesicus along with E. furinalis and E. andinus (Figure 2). Although these species tend to overlap in cranial measurements, the variation observed in DFA 1 is positively influenced by the CCL, I-M3 and C-M3, while those that intervene negatively are $B C B$ and $C-C$. For the DFA 2, the highest positive values are provided by MB, GLS, and I-M3, while the negative variables were IOB and M3-M3 (Table 1).

We obtained four cyt- $b$ (GenBank accession numbers MW488942-MW488945), two COI (MW490595; MW490596], and four ND1 [MW488933-MW488936) individual sequences of specimens from the Bolivian-Tucumanian forest of Bolivia. A BLAST (Basic Local Alignment Search Tool) search of these cyt- $b$ and ND1 sequences showed a range between $94.5 \%$ and $92.9 \%$ of identity with $E$. furinalis and $E$. diminutus. The specimens from Province of Florida, Bolivia, showed high cyt- $b$ distances (Table 2 ) when compared with the cyt- $b$ sequences of $E$. chiriquinus from Colombia (11\%), E. andinus (9.4 to $9.8 \%$ ), and E. furinalis (7.5 to $7.8 \%)$. For the ND1 gene, the distances from Eptesicus from Bolivia were 8.7 to $8.8 \%$ with E. chiriquinus (MHN-UCa 1951), $11.2 \%$ with $E$. andinus, and 6.3 to $6.5 \%$ with $E$. furinalis (Table 2). Similarly, the COI distances were between 9.7 to $12.7 \%$ with $E$. andinus, and over $7.0 \%$ with $E$. chiriquinus and $E$. furinalis (see Appendix 2). In addition, the Bayesian Inference and Maximum Likelihood consensus trees for the single and concatenated sets of mitochondrial genes show



Figure 2. PCA (top) and DFA (bottom) graphs of 14 cranial and external measurements of six Eptesicus species: triangle E. diminutus ( $n=10)$; cross, E. furinalis $(n=44)$; circle full, E. langeri $(n=19)$; diamond, E. andinus ( $n=13)$; triangle invert, E. chiriquinus ( $n$ $=21$ ); X, E. brasiliensis ( $n=4$ ). Holotype of E. langeri (asterisk); holotype of E. andinus (filled diamond 1); E. chiralensis (filled diamond 2); E. montosus (filled diamond 3). a monophyletic group conformed by the sequences of the Bolivian-Tucumanian forest of Bolivia specimens (Figure 3 and Appendix 1 to 3). Based on the results of the molecular and morphological analyses we described the BolivianTucumanian forest specimens as a new species of Eptesicus.

\section{Discussion}

Our results show that, morphologically the BolivianTucumanian forest specimens described here as Eptesicus langeri sp. nov. are part of the long-haired species of the subgenus Eptesicus that include high elevation Andean species such as $E$. andinus and $E$. chiriquinus, and cranially is similar to E. andinus rather to any other Eptesicus taxa. Most of the Neotropical Eptesicus have connected sagittal and nuchal ridges (in E. brasiliensis, E. chiriquinus, E. furinalis, E. innoxius, and E. taddeii), being E. andinus the exception, as this presents poorly developed ridges, creating a flattened and triangular space in dorsal view (Simmons and Voss 1998; Miranda et al. 2006; Tirira 2007; RamírezChaves 2008). In addition, Neotropical Eptesicus have been grouped by hair length (Davis and Gardner 2008; Díaz et al. 2016; Sánchez et al. 2019), in short (less than $8.0 \mathrm{~mm}$ : E. brasiliensis, E. furinalis, E. taddeii and E. ulapesensis) and long-haired species (larger than $8.0 \mathrm{~mm}$ : $E$. andinus and $E$. chiriquinus). In contrast, some authors (e. g., García-García et al. 2007; Gregorin and Loureiro 2011), provided longer hair measurements for E. brasiliensis (9 to $10 \mathrm{~mm}$ ), overlapping mainly with E. chiriquinus (Simmons and Voss 1998).

Table 1. PCA and DFA results for 14 cranial variables of 138 specimens belonging to five Eptesicus species.

\begin{tabular}{|c|c|c|c|c|}
\hline \multirow[t]{2}{*}{ Variable } & \multicolumn{2}{|c|}{$\begin{array}{c}\text { Principal Component } \\
\text { Analysis }\end{array}$} & \multicolumn{2}{|c|}{$\begin{array}{l}\text { Discriminant Function } \\
\text { Analysis }\end{array}$} \\
\hline & PCA 1 & PCA 2 & DFA 1 & DFA 2 \\
\hline GLS & 0.966 & -0.094 & -28.789 & 47.078 \\
\hline $\mathrm{BCH}$ & 0.824 & 0.081 & 3.874 & -33.086 \\
\hline$B L$ & 0.940 & -0.173 & -14.950 & 3.470 \\
\hline PAL & 0.931 & -0.041 & 8.328 & 17.541 \\
\hline P-M3 & 0.932 & -0.127 & 12.880 & 5.316 \\
\hline $\mathrm{MB}$ & 0.896 & -0.001 & 8.694 & 60.880 \\
\hline M3-M3 & 0.926 & -0.050 & 5.516 & -4.856 \\
\hline $\mathrm{C}-\mathrm{C}$ & 0.866 & -0.060 & -6.571 & -15.323 \\
\hline I-M3 & 0.955 & -0.147 & 25.194 & 29.397 \\
\hline C-M3 & 0.955 & -0.138 & 23.414 & -26.821 \\
\hline $\mathrm{CCL}$ & 0.964 & -0.075 & 45.083 & -32.240 \\
\hline $\mathrm{IOB}$ & 0.855 & -0.001 & 6.330 & -1.828 \\
\hline POC & 0.608 & 0.711 & 8.475 & -24.852 \\
\hline $\mathrm{BCB}$ & 0.740 & 0.479 & -1.940 & -26.743 \\
\hline Eigenvalue & 11.039 & 0.850 & 9.330 & 11.490 \\
\hline$\%$ variance & 78.9 & 6.1 & 73.0 & 11.7 \\
\hline \multicolumn{5}{|l|}{$\%$ variance } \\
\hline accumulated & 78.9 & 84.9 & 73.0 & 84.7 \\
\hline
\end{tabular}




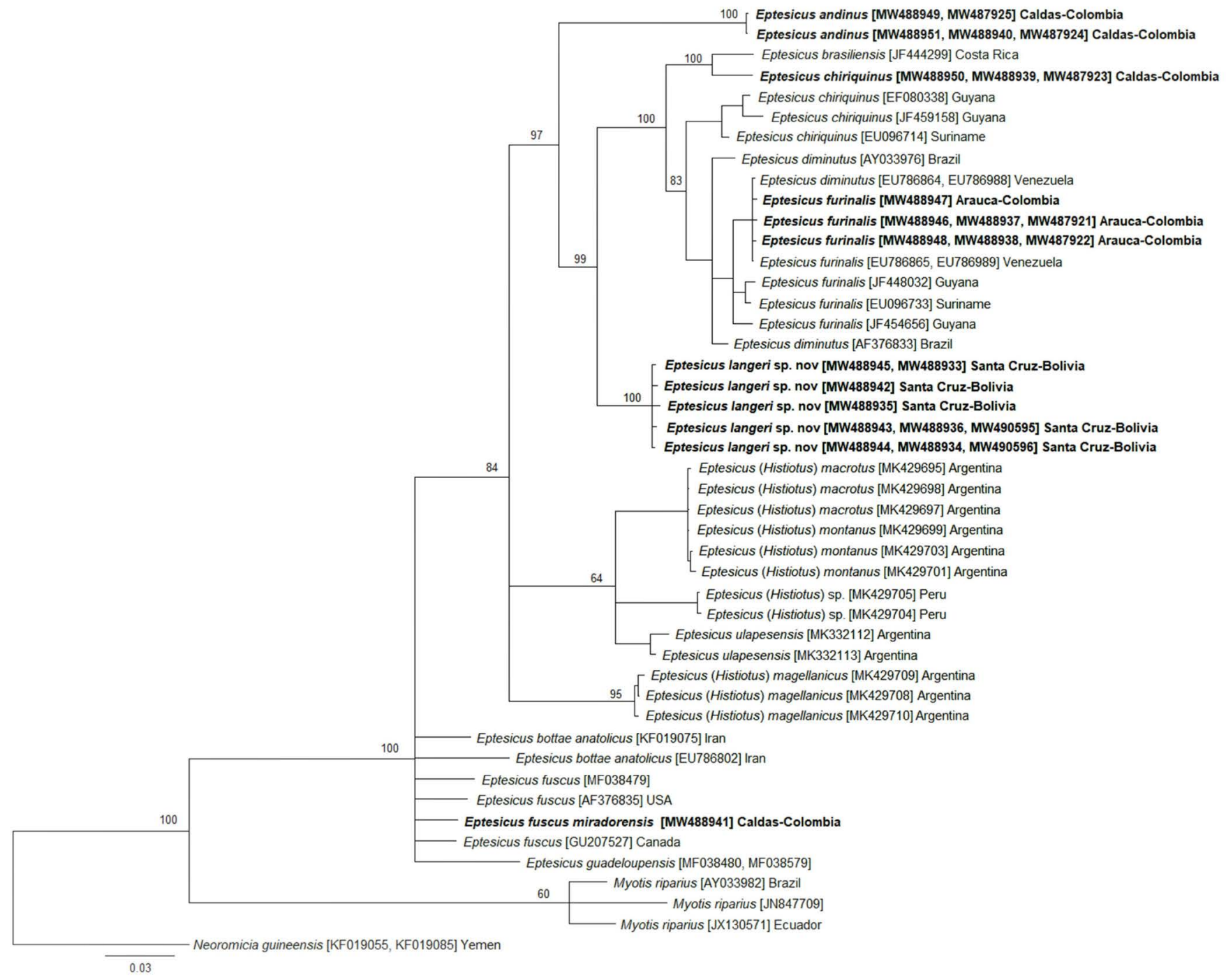

Figure 3. Phylogenetic tree inferred from the concatenation of cyt- $b, \mathrm{ND} 1$ and COI genes partial sequences of bats specimens collected in the present study (in bold) and sequences from GenBank accession numbers in brackets (cyt- $b$, ND1 and COI respectively) using Bayesian inference (BI) with the GTR+F+l+G4 evolutionary model, and Neoromicia guineensis and Myotis riparius were used as outgroup. Bayesian posterior probabilities (\%) are indicated in the nodes.

Despite the suggested morphological groups, our phylogenetic analyses show that these characters are not related to monophyletic clades, as shown by the position of E. langeri, $E$. chiriquinus and E. andinus in the phylogenetic trees (Figure 3 and Appendix 1 to 2).

The lack of genetic data for $E$. andinus in previous phylogenetic analyses or species descriptions (Giménez et al. 2019; Sánchez et al. 2019), limited the assessment of the morphological and phylogenetic association within the Neotropical Eptesicus. In this way, our work is also filling these gaps by including and analysing the phylogenetic position of $E$. andinus for first time. In addition, our work showed that the diversity of Neotropical Eptesicus has been underestimated as suggested by newly proposed species (Sánchez et al. 2019). Finally, the systematics of Eptesicus and Histiotus is not deeply understood, and integral revisions of both taxa are needed (Giménez et al. 2019; Sánchez et al. 2019), therefore, the information that we provide here can be useful for additional integrative analyses at continental scale.
Taxonomy

Family Vespertilionidae Gray 1821

Genus Eptesicus Rafinesque, 1820

Subgenus Eptesicus Rafinesque, 1820

Eptesicus langeri sp. nov.

Holotype: The holotype is an adult lactating female, preserved as skin and skull, and deposited in the mammal collection of the Museo de Historia Natural Noel Kempff Mercado, Universidad Autónoma Gabriel René Moreno, Santa Cruz, Bolivia, with catalogue number MNKM-5584. Collected on December 01, 2013 by Luis H. Acosta, field number L. Acosta 732, at an elevation of 2,020 masl, in a fern grove of the Bolivian-Tucumanian forest surveyed during a biological diagnosis of the locality El Cedral-Agua Rica.

Type locality: El Cedral-Agua Rica, 15 km from the Municipality of Samaipata, Province of Florida, Department of Santa Cruz, Bolivia (-18 $13^{\prime} 10.55^{\prime \prime}$ S, $-63^{\circ} 47^{\prime} 49.74^{\prime \prime}$ W; 2,020 masl (Figure 1). 


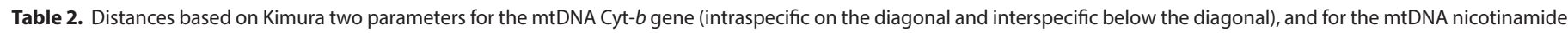
adenine dinucleotide dehydrogenase (ND1) gene (in bold, above the diagonal).

\begin{tabular}{|c|c|c|c|c|c|c|c|c|c|c|c|c|c|}
\hline & Species & 1 & 2 & 3 & 4 & 5 & 6 & 7 & 8 & 9 & 10 & 11 & 12 \\
\hline 1 & Eptesicus sp. nov (Bolivia) & $0.000 / 0.000$ & 0.112 & $0.068-0.072$ & $0.082-0.084$ & $0.205-0.213$ & & $0.167-0.170$ & $0.061-0.072$ & & & & \\
\hline 2 & E. andinus & $0.094-0.098$ & 0.00 & 0.093 & 0.101 & 0.187 & & 0.137 & $0.093-0.101$ & & & & \\
\hline 3 & E. furinalis & $0.076-0.079$ & $0.116-0.135$ & 0.000 & $0.053-0.056$ & $0.191-0.219$ & & $0.165-0.176$ & $0.000-0.048$ & & & & \\
\hline 4 & E. chiriquinus & $0.111-0.117$ & $0.107-0.111$ & $0.078-0.093$ & - & 0.236 & & 0.152 & $0.053-0.060$ & & & & \\
\hline 5 & E. bottae anatolicus & $0.202-0.208$ & $0.194-0.205$ & $0.205-0.218$ & 0.232 & - & & 0.182 & $0.183-0.193$ & & & & \\
\hline 6 & E. guadeloupensis & $0.118-0.140$ & $0.191-0.203$ & $0.135-0.176$ & 0.180 & 0.202 & - & & & & & & \\
\hline 7 & E. fuscus & $0.114-0.136$ & $0.164-0.183$ & $0.120-0.149$ & $0.149-0.152$ & $0.170-0.191$ & $0.078-0.093$ & 0.080 & $0.160-0.169$ & & & & \\
\hline 8 & E. diminutus & $0.072-0.079$ & $0.124-0.134$ & $0.000-0.031$ & $0.063-0.078$ & $0.208-0.214$ & $0.163-0.176$ & $0.137-0.149$ & 0.027 & & & & \\
\hline 9 & E. (Histiotus) montanus & $0.128-0.143$ & $0.131-0.142$ & $0.133-0.161$ & $0.144-0.145$ & $0.196-0.199$ & $0.171-0.172$ & 0.151 .0 .159 & $0.128-0.134$ & $0.001-0.003$ & & & \\
\hline 10 & E. (Histiotus) magellanicus & $0.093-0.103$ & $0.124-0.136$ & $0.120-0.132$ & $0.139-0.143$ & $0.181-0.183$ & $0.159-0.160$ & $0.134-0.154$ & $0.132-0.145$ & $0.132-0.137$ & $0.002-0.004$ & & \\
\hline 11 & E. (Histiotus) sp. & $0.128-0.134$ & $0.138-0.147$ & $0.155-0.172$ & $0.149-0.152$ & $0.195-0.196$ & $0.176-0.178$ & $0.158-0.176$ & $0.139-0.155$ & $0.072-0.073$ & $0.125-0.130$ & 0.001 & \\
\hline 12 & E. (Histiotus) macrotus & $0.128-0.138$ & $0.131-0.143$ & $0.133-0.156$ & $0.144-0.145$ & 0.196 & $0.171-0.172$ & $0.151-0.159$ & $0.127-0.136$ & $0.000-0.004$ & $0.132-0.135$ & $0.072-0.074$ & $0.000-0.001$ \\
\hline
\end{tabular}

Paratypes: 18 individuals, six females (MNKM 4436, 5088, $5117,5585,5587,5588$ ) and seven males (MNKM 4678, 4679, $5126,5590,5591,5592,5692)$ from the type locality; four females (MNKM 5586, 5589, 5636, 5676) from Agua Clarita (-17 $56^{\prime} 47.71^{\prime \prime} \mathrm{S},-64^{\circ} 08^{\prime} 0.28^{\prime \prime} \mathrm{W}, 1,578 \mathrm{masl}$ ); and one female (MNKM 5697) from Reserva Municipal El Chape (-18 $01^{\prime} 21.46^{\prime \prime} S$, $-63^{\circ}$ $56^{\prime} 50.23^{\prime \prime} \mathrm{W}, 2,054$ masl). External and cranial measurements are provided in Appendix 3 to 5.

Distribution: Eptesicus langeri sp. nov. is known from three localities: i) El Cedral-Agua Rica, ii) Agua Clarita, and iii) the Reserva Municipal El Chape, all three in the Province of Florida, Department of Santa Cruz, Bolivia (Figure 1).

Nomenclatural statement: A life science identifier (LSID) number was obtained for new species described herein: urn:Isid:zoobank.org:act:3723D032-6800-401F-ACEE0326F1AE72B1.

Etymology: The epithet langeri is in honour of Fray Andrés Ma Langer o.p., a Dominican parish priest who made important contributions to the mammalogy of the inter-Andean valleys of Bolivia, especially in the Province of Florida of the Department of Santa Cruz. Several specimens collected by Fray Andrés Ma Langer are deposited and catalogued at the Museo de Historia Natural Noel Kempff Mercado.

Diagnosis: Eptesicus langeri is a medium-sized bat (forearm length 40 to $44 \mathrm{~mm}$ ), with dorsal fur that is long $(\sim 8 \mathrm{~mm})$, dark brown or orange-brown in females and dark brown in males (Figure 4). The skull has developed sagittal and lambdoidal ridges, that do not reach the posterior region of the skull (Figure 5). A developed preorbital process between the smallest width of the interorbital and postorbital (Figure 6). Coronoid process tall (Figure 5).

Description: Eptesicus langeri is a medium-sized bat, similar in size to $E$. furinalis and $E$. andinus (Table 3). The dorsal and ventral fur is bicoloured with dark bases and light tips (dark brown to dark orange, near one quarter hair length; Figure 4). Both sexes present the dorsal fur longer between the shoulders ( 7 to $9 \mathrm{~mm}$ ) and shorter in the middle part of the body $(\sim 6 \mathrm{~mm})$, the ventral region hairs differ from the back by being lighter. Males have a longer dark brown dorsal fur between the shoulders $(\sim 9 \mathrm{~mm})$ and shorter in the middle of the back $(\sim 7 \mathrm{~mm})$. Pregnant and lactating females have dorsal fur coloured "orange-brown".

The skull is long, with developed sagittal and lambdoidal ridges. The sagittal crest gives the skull an elevated appearance that is more evident in the middle part of the cranial vault, while the lambdoidal or nuchal crest is developed at the edges of the occipitoparietal suture. Both ridges do not come into contact in the posterior region of the skull, leaving a gap between them (Figure 5).
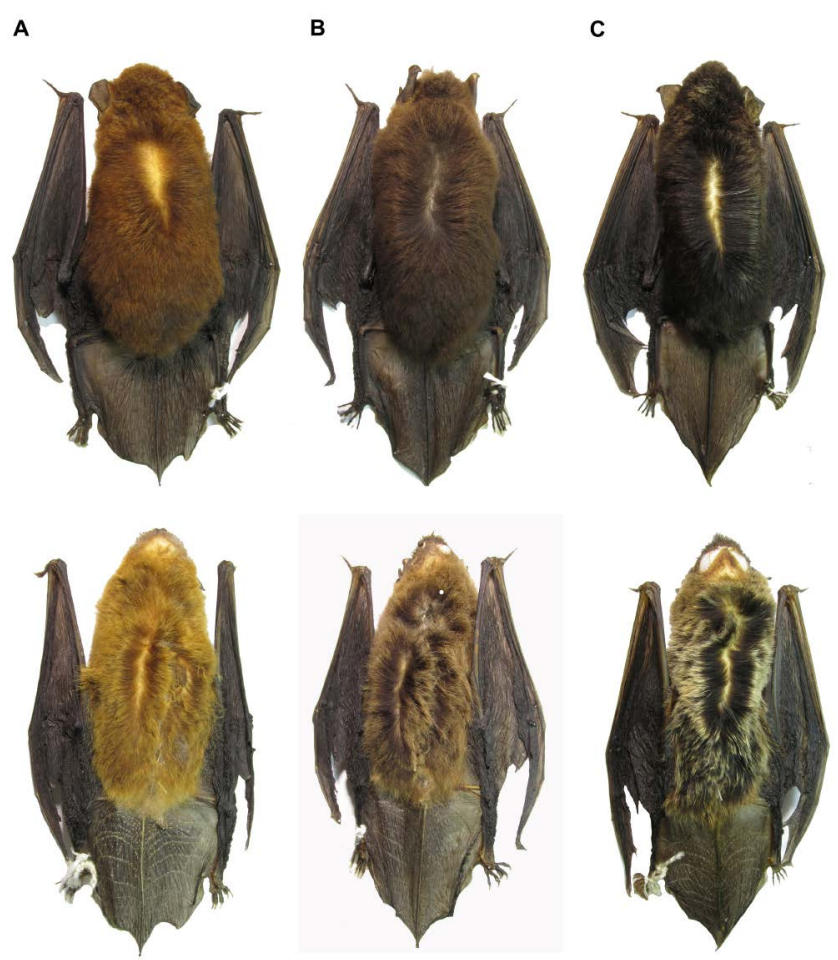

Figure 4. Dorsal and ventral view of the coat colour pattern. From left to right: $A$. female (MNKM-5584 holotype) and B. male (MNKM- 5592 paratype) of E. langeri sp. nov. and C. E. andinus (MNKM-5598). 


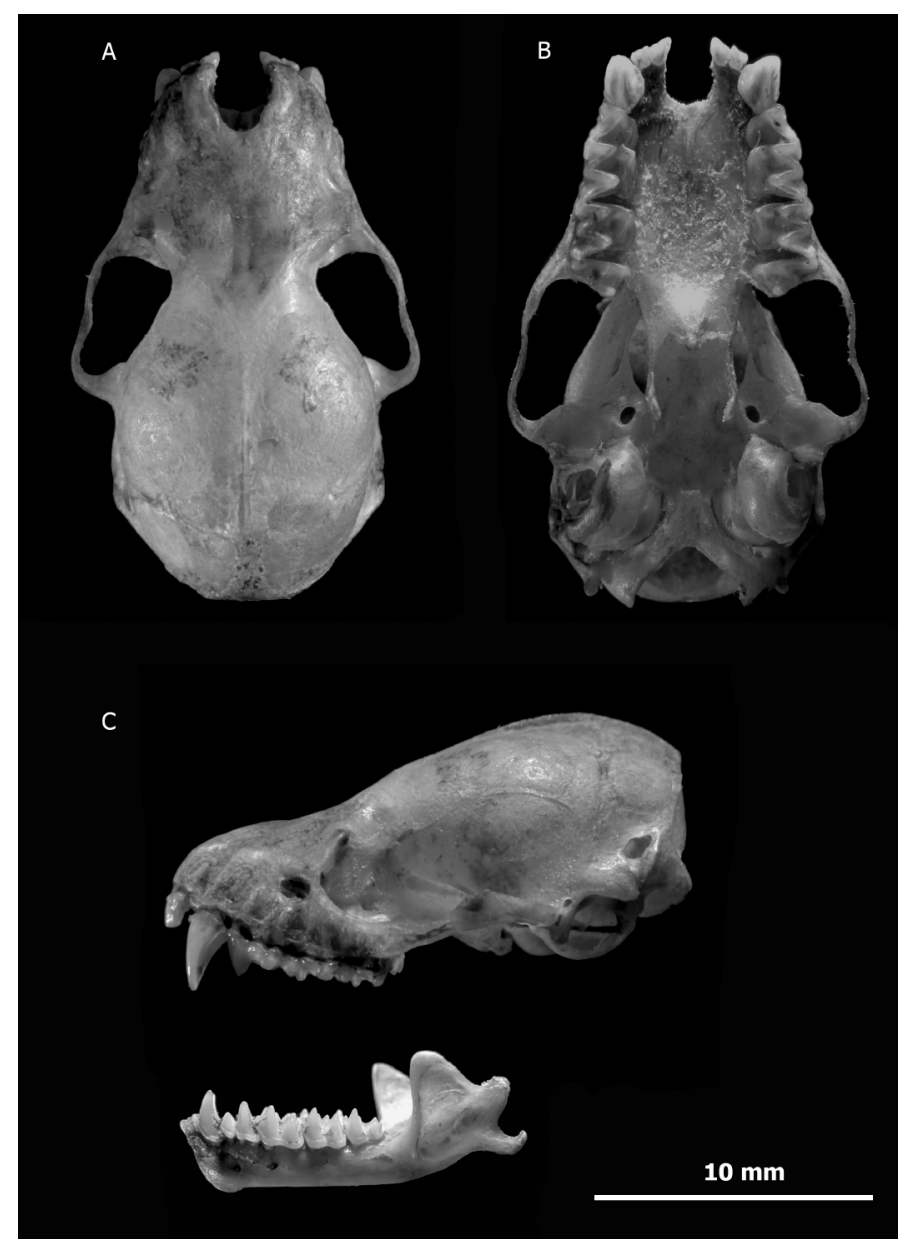

Figure 5. Dorsal (A), ventral (B) and lateral (C) views of the skull of the holotype of Eptesicus langeri sp. nov (MNKM-5584).
Eptesicus langeri presents a well-developed frontal preorbital processes (Figure 6). In adult females these processes are more developed than in adult males. The upper internal incisors are larger than the external incisors. There is a small diastema between the upper external incisors and canine. The canine is attached to the premolar. First and second upper molars are similar, and the occlusal surfaces are W-shaped. The third upper molar is smaller than the rest of the molars and posteriorly extends beyond the anterior insertion of the zygomatic arches. The lower external incisors are in contact with the canines. The lower canine is slightly inclined towards the back, and in contact with first lower premolar which is approximately half the height of the canine; second lower premolar is higher than the first and in contact with first lower molar.

The mandible has a triangular and slightly curved coronoid process. The anterior part of the dentary has a straight oblique mandibular line; the mandibular process is slightly curved with a rounded end. A semi-circular mandibular incisure is located between the coronoid process and the anterior part of the dentary; the angular process is dorsally curved, and the mandibular ramus has a central depression (Figure 5).

Comparisons: Eptesicus langeri is a medium-sized bat (FA: 40.09 to $44.1 \mathrm{~mm}$; GLS: 14.75 to $16.15 \mathrm{~mm}$ ) with a dorsal and ventral fur length between 6.0 to $10.0 \mathrm{~mm}$. It can be easily distinguished of other South American Eptesicus based on the forearm length, E. diminutus $<37.0 \mathrm{~mm}, E$. innoxius < $39.0 \mathrm{~mm}$, E. furinalis $<41.0 \mathrm{~mm}$, E. taddeii $>44.1 \mathrm{~mm}$ and $E$. fuscus miradorensis $>49.0 \mathrm{~mm}$. E. langeri is smaller than $E$.



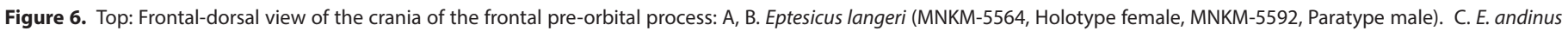

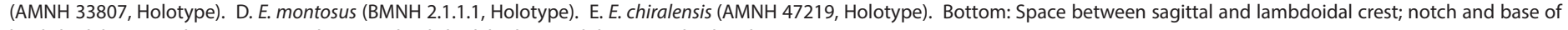
lambdoidal crest (red arrows); space between lambdoidal ridges and the parietal (white line). 
brasiliensis, E. chiriquinus, E. taddeii and E. ulapesensis, especially in the GLS (Table 3), and discrete characters of the skull and skin (Appendix 9). Eptesicus langeri is characterized by a highly developed preorbital process, which is poorly developed in E. andinus, E. furinalis (Figure 6), E. brasiliensis, $E$. fuscus miradorensis, E. innoxius, and E. taddeii, whereas in $E$. chiriquinus this process is evident but not well-developed. Based on dorsal fur length, $E$. langeri can be differentiated of E. furinalis $(<7.0 \mathrm{~mm})$ and E. ulapesensis $(\sim 6.0 \mathrm{~mm})$. In E. taddeii the coat is reddish and $7.0 \mathrm{~mm}$ long (Miranda et al. 2006).

Comparison with holotypes of Eptesicus andinus (AMNH 33807), E. chiralensis (AMNH 47219), and E. montosus (BMNH 2.1.1.1): Eptesicus langeri can be differentiated from $E$. andinus and two of its junior synonyms ( $E$. chiralensis and $E$. montosus) by cranial characteristics including: a) lambdoidal crest developed in the lateral region of the interparietal in E. langeri, vs. poorly developed in E. andinus, E. chiralensis, and E. montosus (Figures 6 to 8). B) base of the lambdoidal crest, broad in posterior view and with a smooth notch in the middle region in E. langeri, vs. lacking a notch and almost straight in E. andinus, E. chiralensis, and E. montosus (Figure 6). C) Frontal preorbital process present in $E$. langeri vs. poorly developed in E. andinus, E. chiralensis, and E. montosus (Figures 6 to 7). D) circular appearance in the nasal-premaxillary region in $E$. langeri, vs. rectangular in $E$. andinus, E. chiralensis and E. montosus (Figure 8). E) angular process of the mandible with a robust tip in E. langeri, vs. delicate in E. andinus, E. chiralensis and E. montosus (Figure 8). F) ascending ramus of the coronoid process lacking a steep slope in E. langeri $\left(31^{\circ}\right)$, E. andinus $\left(30^{\circ}\right)$ and $E$. chi-

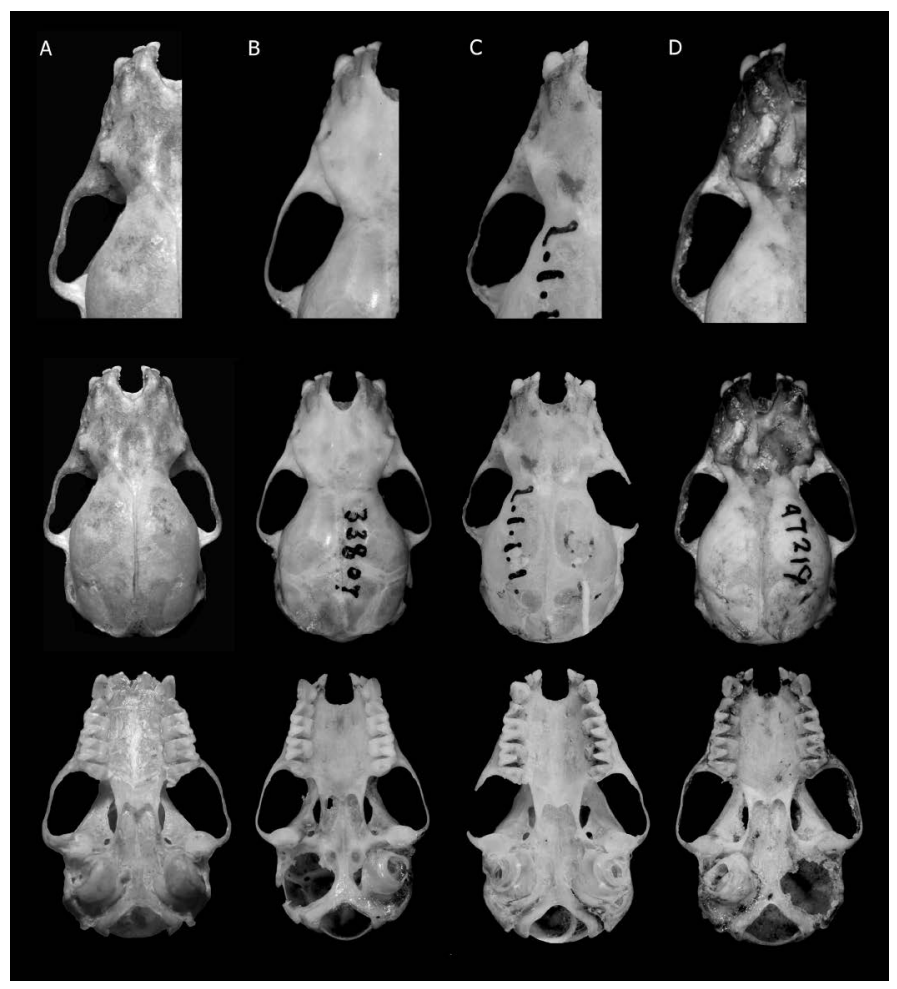

Figure 7. Dorsal, and ventral, view of skulls (left to right) of A. Eptesicus langeri sp. nov (MNKM-5592, Paratype). B. E. andinus (AMNH 33807, Holotype). C. E. montosus (BMNH 2.1.1.1, Holotype). D. E. chiralensis (AMNH 47219, Holotype). ralensis $\left(35^{\circ}\right)$, vs. with steep slope in E. montosus (40; Figure 8). G) ramus of ventral mandible curved in E. langeri, vs. smoothly curve in E. andinus and E. montosus, and straight in E. chiralensis (Figure 8). Eptesicus langeri overlaps in some external and cranial measurements with Eptesicus andinus, E. chiralensis, and E. montosus although E. langeri can be separated when the postorbital width and cranial index are plotted (Appendix 6).

Ecology: The type locality is part of the Bolivian-Tucumanian forest, characterized by Chari (Parapiptadenia excelsa) and Tipa (Tipuana tipu) trees, and connected to the Andean vegetation of the Peruvian-Bolivian Yungas (Navarro 2011). Specimens of the type locality were collected from 19:24 to 23:30 h. Most specimens were collected using mist nets installed at a height of 5 to $8 \mathrm{~m}$ above ground in forest clearings (newly opened road) of a secondary road. Lactating females and males with testicles in scrotal position have been recorded from November to January. Specimens from Agua Clarita were collected inside a hollow of a standing tree. Other bat species reported at the type locality are Anoura geoffroyi, Sturnira lilium, S. oporaphilum, Chrotopterus auritus, Desmodus rotundus, Platyrrhinus masu, Myotis nigricans, and $M$. keaysi.

We suggest that discreet dental skull characters should be used together with some measurements for an accurate identification of E. langeri. Thus, we propose the following identification key for some South American Eptesicus (sensu Davis and Gardner 2008), with emphasis on some cranial variables:

\section{Taxonomic key}

1. Ears longer than $20.0 \mathrm{~mm}$, extending well beyond muzzle ...subgenus Histiotus

1a. Ears normal, less than $20.0 \mathrm{~mm}$, not extending beyond muzzle ..subgenus Eptesicus 2

2. Skull longer than $16.3 \mathrm{~mm}$; upper toothrow $>6.3 \mathrm{~mm}$....3

2a. Skull less than $16.3 \mathrm{~mm}$; upper toothrow less than $6.3 \mathrm{~mm}$ . .7

3. Forearm greater than $49.0 \mathrm{~mm}$

...Etesicus fuscus miradorensis

3a. Forearm less than $49.0 \mathrm{~mm}$ 4

4.U-shaped nasal opening . ..Eptesicus brasiliensis

4a. V-shaped nasal opening .5

5. Dorsal fur longer than $12.0 \mathrm{~mm}$...........Eptesicus chiriquinus 5a. Dorsal fur less than $12.0 \mathrm{~mm}$... .6

6. Skull length between 17.3 to $18.4 \mathrm{~mm}$......Eptesicus taddeii 6a. Skull length between 15.9 to $17.0 \mathrm{~mm}$

Eptesicus ulapesensis

7. Skull less than $13.6 \mathrm{~mm}$; upper toothrow less than $5.0 \mathrm{~mm}$ Eptesicus diminutus

7a. Skull longer than $13.6 \mathrm{~mm}$; upper toothrow longer than $5.0 \mathrm{~mm}$ . .8

8. Sagittal and lambdoidal crests connected ............................9 

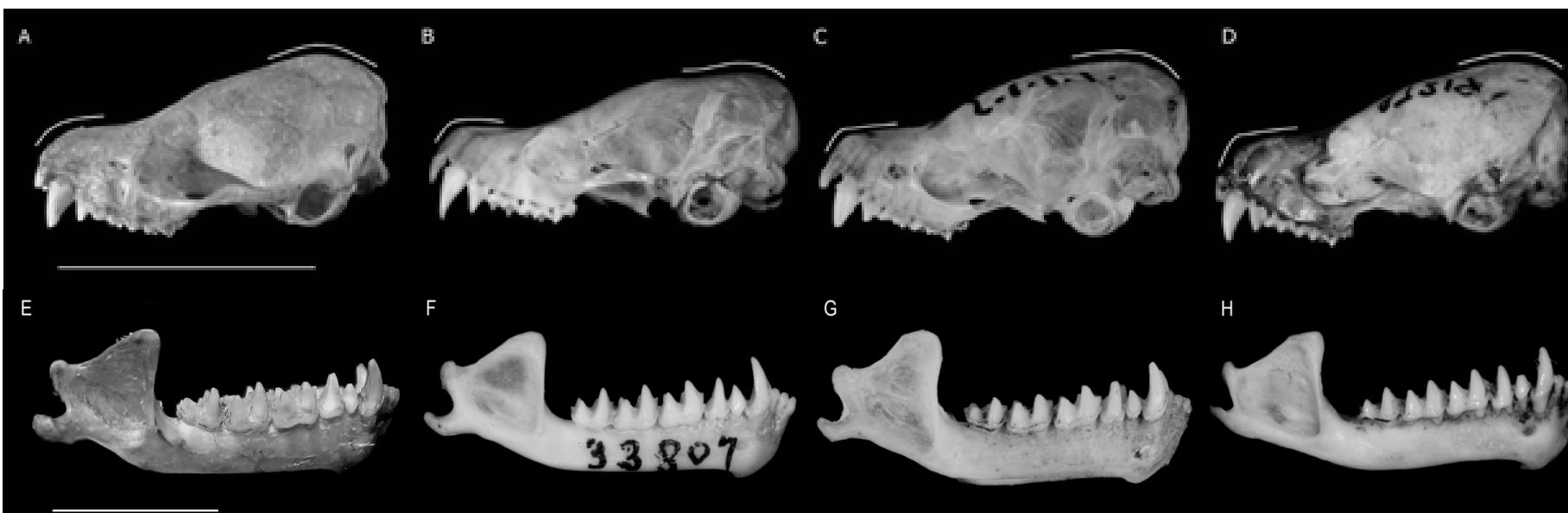

F

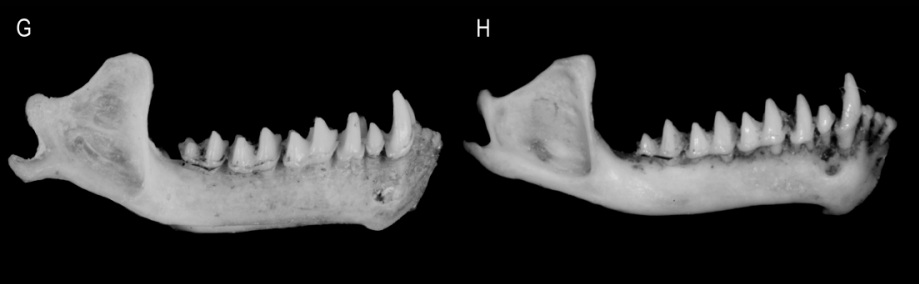

Figure 8. Lateral view of the skull, the white lines show the shape of the rostrum and skull: A. Eptesicus langeri sp. Nov (MNKM-5592, Paratype). B. E. andinus (AMNH 33807, Holotype)

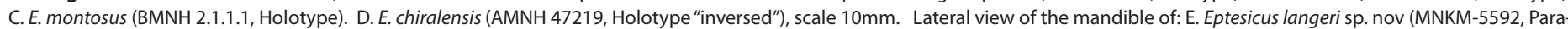
type). F. E. andinus (AMNH 33807, Holotype). G. E. montosus (BMNH 2.1.1.1, Holotype). H. E. chiralensis (AMNH 47219, Holotype), scale 5mm.

8a. Skull with separate sagittal and lambdoidal ridges forming a triangular flat bone 10

9. Pale greyish brown hair colour ...Eptesicus innoxius

9a. Dark brown to blackish brown hair colour

...Eptesicus furinalis

10. Skull with very poorly developed/absent sagittal and lambdoidal ridges, poorly developed preorbital process ..Eptesicus andinus

10a. Skull with evident/developed sagittal and lambdoidal crests, preorbital process present ...Eptesicus langeri

\section{Acknowledgements}

L. H. A. S. and J. L. P. U. thank J. García for the trust and unconditional predisposition to carry out the work on his property and to the community members of the town of Agua Rica. E. Caballero, R. C. Paca, W. Montaño, F. Morezapiri, P. Justiniano, N. Margot Baltazar, L. A. Núñez, R. Blanco, C. A. Terceros, I. Solís, E. Pinto, C. Velis, W. Alvis, G. Sánchez, J. Gonzales, V. Bejarano, L. Castro, and V. Hurtado, for all the help given in the different field campaigns carried out in the town of Agua Rica. To the Pampagrande community for all the information gathered in the collections of the different biological samples that arrived at the Church Parish of this locality, without a doubt they were and are contributions of great importance for the local fauna of this region of the country. To K. Rivero for her unconditional support in all the field work carried out in Agua Rica. To the ANCB-SC-UPSA for the economic support in the last field work on the study area, especially to G. Mejía, C. G. Ugarteche and T. Vranjican. Thanks to Roberto Porleta Miguez (BMNH), M. Ingala (AMNH) and J. Salazar Bravo (TTU), for providing us with the photographs of the different holotypes, which were used for the comparisons. We would also like to thank A. Caicedo (PUCE), R. Barquez (PIDBA, CONICET, PCMA), N. Simmons (AMNH), L. Loureiro (ROM), and A. Lutz (CONICET) for providing us with material for the preparation of this work. H.E.R.C. thanks Y. Muñoz Saba and H. López (ICN), R. Portela Miguez, L. Tomsett, P. Jenkins and L. McCoy (BMNH), M. Díaz (CML), B. Patterson (FMNH), R. Voss and E. Westwig (AMNH), O. Murillo and A. Ruiz (UV), S. Ayerbe and P. Rivas (MHNUC), S. Solari and J. Berrío (CTUA), A. Rodríguez (MUD), Andrés F. Tamayo-Zuluaga (MHN-UCa), and Tatiana Velásquez, M. Rodríguez-Posada, D. Morales-Martínez for the support provided to this research. HERC also thanks the Research board of National Universidad Nacional de Colombia, Bogotá (project 8697), the Vicerrectoría de Investigaciones y Posgrados, Universidad de Caldas (projects 0743919, 1374819, and 0277620), the Vicerrectoría de Investigaciones y Posgrados of Universidad de Caldas and the Ministry of Science, Technology, and Innovation of Colombia (MinCiencias; project code 112777758193; execution contract number 858-2017), and The Rufford Foundation (Grants 23710-1 and 29491-2) for support. L. Emmons, V. Vroomans and D. I. Rumiz made valuable suggestions for improving previous versions of this document.

\section{Literature cited}

Aguirre, L. F., C. J. Mamani, K. Barboza-Marquez and H. MantillaMeluk. 2010. Lista actualizada de los murciélagos de Bolivia. Revista Boliviana de Ecología y Conservación Ambiental 27:1-7. Aguirre, L. F., T. Tarifa, R. B. Wallace, N. Bernal H., L. Siles, E. Aliaga-Rossel and J. Salazar-Bravo. 2019. Lista actualizada y comentada de los mamíferos de Bolivia. Ecología en Bolivia 54:107-147.

Anderson, S. 1997. Mammals of Bolivia, taxonomy, and distribution. Bulletin of the American Museum of Natural History 231:1-652.

Barquez, R. M. and M. Díaz. 2020. Nueva guía de los murciélagos de Argentina. Con la colaboración de María Eugenia Montani y María Julieta Pérez. Publicación Especial No 3 PCMA (Programa de Conservación de los Murciélagos de Argentina). Tucumán, Argentina.

Baud, F. J. And H. Menu. 1993. Paraguayan bats of the genus Myotis, with a redefinition of M. simus (Thomas, 1901). Revue Suisse de Zoologie 100:595-607. 
Bickham, J. W., J. C. Patton, D. A. Schlitter, I. L. Rautenbach And R. L. Honeycutt. 2004. Molecular phylogenetics, karyotypic diversity, and partition of the genus Myotis (Chiroptera: Vespertilionidae). Molecular Phylogenetics and Evolution 33:333-338.

Bickham, J. W., C. C. Wood and J. C. Patton. 1995. Biogeographic implications of Cytochrome b sequences and allozymes in Sockeye (Oncorhynchus nerka). Journal of Heredity 86:140-144.

Brown, M. T. and L. R. Wicker. 2000. Discriminant Analysis. Pp. 209-235, in Handbook of Applied Multivariate Statistics and Mathematical Modeling (Brown, H. E. A. T. D. eds.). Academic Press. San Diego, U.S.A.

Burgin, C. J., J. P. Colella, P. L. Kahn and N. S. Upham. 2018. How many species of mammals are there? Journal of Mammalogy 99:1-11.

Davis, W. B. 1966. Review of South American bats of the genus Eptesicus. The Southwestern Naturalist 11:245-274.

Davis, W. B. and A. L. Gardner. 2008. Genus Eptesicus Pp. 440450, in Mammals of South America: Marsupials, Xenarthrans, Shrews and Bats (Gardner, A. L. ed.). University of Chicago Press. Chicago and London.

Díaz, M. M., S. Solari, L. F. Aguirre, L. M. S. Aguiar and R. M. Barquez. 2016. Clave de Identificación de los Murciélagos de Sudamérica-Chave de Identificação dos Morcegos da America do Sul. PCMA (Programa de Conservación de los Murciélagos de Argentina). Argentina.

Drummond, A.J., B. Ashton, M. Cheung, J. Heled, M. Kearse, R. Moir, H.S. Stones, T. Thierer and A. Wilson. 2009. Geneious v8.14. https://WWW. geneious.com

García-García, J. L., A. Santos-Moreno, A. M. Alfaro and A. Soto-Centeno. 2007. Noteworthy records of Eptesicus brasiliensis (Vespertilionidae) from Oaxaca, México. Bat Research News 48:5-6.

Giménez, A. L., N. P. Giannini and F.C. Almeida. 2019. Mitochondrial genetic differentiation and phylogenetic relationships of three Eptesicus (Histiotus) species in a contact zone in Patagonia. Mastozoología Neotropical 26:349-358.

Gregorin, R. AND L. O. Loureiro. 2011. New records of bats for the state of Minas Gerais, with range extension of Eptesicus chiriquinus Thomas (Chiroptera: Vespertilionidae) to southeastern Brazil. Mammalia 75:291-294.

Guindon, S., J.F. Dufayard, V. Lefort, M. Anisimova, W. Hordijk AND O. Gascuel. 2010. New algorithms and methods to estimate maximum-likelihood phylogenies: assessing the performance of PhyML 3.0. Systematic Biology 59:307-321.

Hamilton, P. B., T. M. U. Webster, M. Basiewicz, E. V. Kennedy, E. S. R. De-Bastos and F. Mathews. 2015. A rapid PCR-based test for identification of fifteen British bat species. Conservation Genetics Resources 7:651-657.

Hammer, Ø, D. A. T. Harper and P. D. Ryan. 2001. PAST: Paleontological statistics software package for education and data analysis. Palaeontologia Electrónica 4:1-9.

Hoofer, S. R., And R. A. Van Den Bussche. 2003. Molecular phylogenetics of the chiropteran family Vespertilionidae. Acta Chiropterologica 5:1-63.

Kalyanamoorthy, S., B. Q. Minh, T. K. F. Wong, A. Von Haeseler AND L. S. Jermin. 2017. ModelFinder: fast model selection for accurate phylogenetic estimates. Nature Methods 14:587-589.
Kımura, M. 1980. A simple method for estimating evolutionary rates of base substitutions through comparative studies of nucleotide sequences. Journal of Molecular Evolution 16:111-120.

Kumar, S., G. Stecher, M. LI, C. Knyaz and K. Tamura. 2018. MEGA X: Molecular Evolutionary Genetics Analysis across Computing Platforms. Molecular Biology and Evolution 35:1547-1549.

Minh, B. Q., M. A. T. Nguyen and A. von Haeseler. 2013. Ultrafast Approximation for Phylogenetic Bootstrap. Molecular Biology and Evolution 30:1188-1195.

Miranda, J. M. D., I. P. Bernardi and F. C. Passos. 2006. A new species of Eptesicus (Mammalia: Chiroptera: Vespertilionidae) from the Atlantic Forest, Brazil. Zootaxa 1383:57-68.

Moratelli, R., C. Burgin, V. Cláudio, R. Novaes, A. LópezBaucells and R. Haslauer. 2019. Family Vespertilionidae. Pp. 855-996, in Handbook of the Mammals of the World. Volume 9, Bats (Wilson, D. E., and R. A Mittermeier, eds.). Lynx Edicions, Barcelona.

Navarro, G. 2011. Clasificación de la vegetación de Bolivia. Centro de Ecología Difusión Simón I. Patiño. Bolivia.

Nguyen, L.T., H.A. Schmidt, A. Von Haeseler and B. Q. Minh. 2015. IQ-TREE: a fast and effective stochastic algorithm for estimating maximum-likelihood phylogenies. Molecular Biology and Evolution 32:268-274.

Parson, W., K. Pegoraro, H. Niederstätter, M. Föger and M. Steinlechner. 2000. Species identification by means of the cytochrome b gene. International Journal of Legal Medicine 114:23-28.

Poma-Urey, J. L., L. H. S. Acosta and M. R. Ingala. 2019. Dos especies de Eptesicus Rafinesque, 1820 (Chiroptera, Vespertilionidae) registradas por primera vez en Bolivia. Ecología en Bolivia 54:181-190.

Rambaut, A. 2007. FigTree v1.4.3, A graphical viewer of phylogenetic trees. https://tree.bio.ed.ac.uk/software/figtree/

Ramírez-Chaves, H. E. 2008. Revisión taxonómica de los murciélagos del género Eptesicus Rafinesque, 1820 (Mammalia: Chiroptera: Vespertilionidae) para Colombia. Tesis para optar al título de Maestría, Facultad de Ciencias, Instituto de Ciencias Naturales, Universidad Nacional de Colombia.

RIDGWAY, R. 1912. Color standards and color nomenclature. The author, Washington, U.S.A.

Rodríguez-Posada, M. E., D. M. Morales-Martínez, H. E. RamírezChaves, D. Martínez-Medina, and C. A. Calderón Acevedo. 2021. A new species of Long-eared Brown Bat of the genus Histiotus (Chiroptera) and the revalidation of Histiotus colombiae. Caldasia doi: https://doi.org/10.15446/caldasia.v43n2.85424

Ronquist, F., M. Teslenko, P. Van Der Mark, D. L. Ayres, A. Darling, S. Höhna, B. Larget, L. Liu, M. A. Suchard, and J.P. HuelSENBECK. 2012. MrBayes 3.2: efficient Bayesian phylogenetic inference and model choice across a large model space. Systematic Biology 61:539-542.

Sánchez, R. T., M. E. Montani, I. H. Tomasco, M. M. Díaz, and R. M. Barquez. 2019. A new species of Eptesicus (Chiroptera, Vespertilionidae) from Argentina. Journal of Mammalogy 100:118-129.

Siles, L. 2007. Noteworthy records of Eptesicus chiriquinus and Eptesicus andinus (Vespertilionidae) from Bolivia. Bat Research News 48:31-33. 
Simmons, N. B., And A.L. Cirranello. 2020. Bat species of the world: a taxonomic and geographic database. https://batnames.org/home.html.

Simmons, N. B., ANd R. S. Voss. 1998. The mammals of Paracou, French Guiana, a Neotropical lowland rainforest fauna. Part 1. Bulletin of the American Museum of Natural History 237:1-219.

Thompson, J. D., T. J. Gibson, F. Plewniak, F. Jeanmougin, and D. G. Hıgaıss. 1997. The CLUSTAL_X Windows Interface: Flexible Strategies for Multiple Sequence Alignment Aided by Quality Analysis Tools. Nucleic Acids Research 25:4876-4882.

TiriRA, D. G. 2007. Guía de Campo de los Mamíferos del Ecuador. Ediciones Murciélago Blanco. Publicación Especial sobre los Mamíferos del Ecuador. Quito Ecuador.

Vargas-Espinoza, A. 2007. Familia Vespertilionidae Gray, 1821. Pp. 400, in Historia Natural Distribución y Conservación de los Murciélagos de Bolivia (Aguirre, L. F. ed.). Centro de Ecología y Difusión I. Patiño. Santa Cruz-Bolivia, Bolivia.

Zhang, D., F. GaO, I. Jakovlić, H. Zou, J. ZhanG, W. X. LI, AND G. T. WANG. 2020. PhyloSuite: An integrated and scalable desktop platform for streamlined molecular sequence data management and evolutionary phylogenetics studies. Molecular Ecology Resources 20:348-355.

Associated editor: Sergio Solari

Submitted: January 31, 2020; Reviewed: February 5, 2020.

Accepted: April 13, 2021; Published on line: July 29, 2021. 


\section{Appendix 1}

A) Tree of the mitochondrial cyt- $b$ gene partial sequences of bats specimens collected in the present study (in bold) and sequences from GenBank (accession numbers in brackets), obtained by Bayesian inference (BI) by the evolutionary model GTR+F+I+G4, and Neoromicia guineensis and Myotis riparius were used as outgroup. Bayesian posterior probabilities (\%) are indicated in the nodes. B)Tree of the mitochondrial ND1 gene partial sequences of bats specimens collected in the present study (in bold) and sequences from GenBank (accession numbers in brackets), using Maximum Likelihood (ML) method and GTR+F+G4 model. Numbers at nodes are above-selected branch support analysis from left to right: ultrafast bootstraps values, and Shimodaira-Hasegawa-like approximate likelihood-ratio test (SH-like aLRT). The sequence of Neoromicia guineensis and Myotis riparius were used as outgroup. C) Tree of the mitochondrial COI gene partial sequences of bats specimens collected in the present study (in bold) and sequences from GenBank (accession numbers in brackets), using Maximum Likelihood (ML) method with the TVM+F+R2 evolution model. Numbers at nodes are above-selected branch support analysis from left to right: ultrafast bootstraps values, and Shimodaira-Hasegawa-like approximate likelihood-ratio test (SH-like aLRT). The sequence of Myotis riparius was used as outgroup.

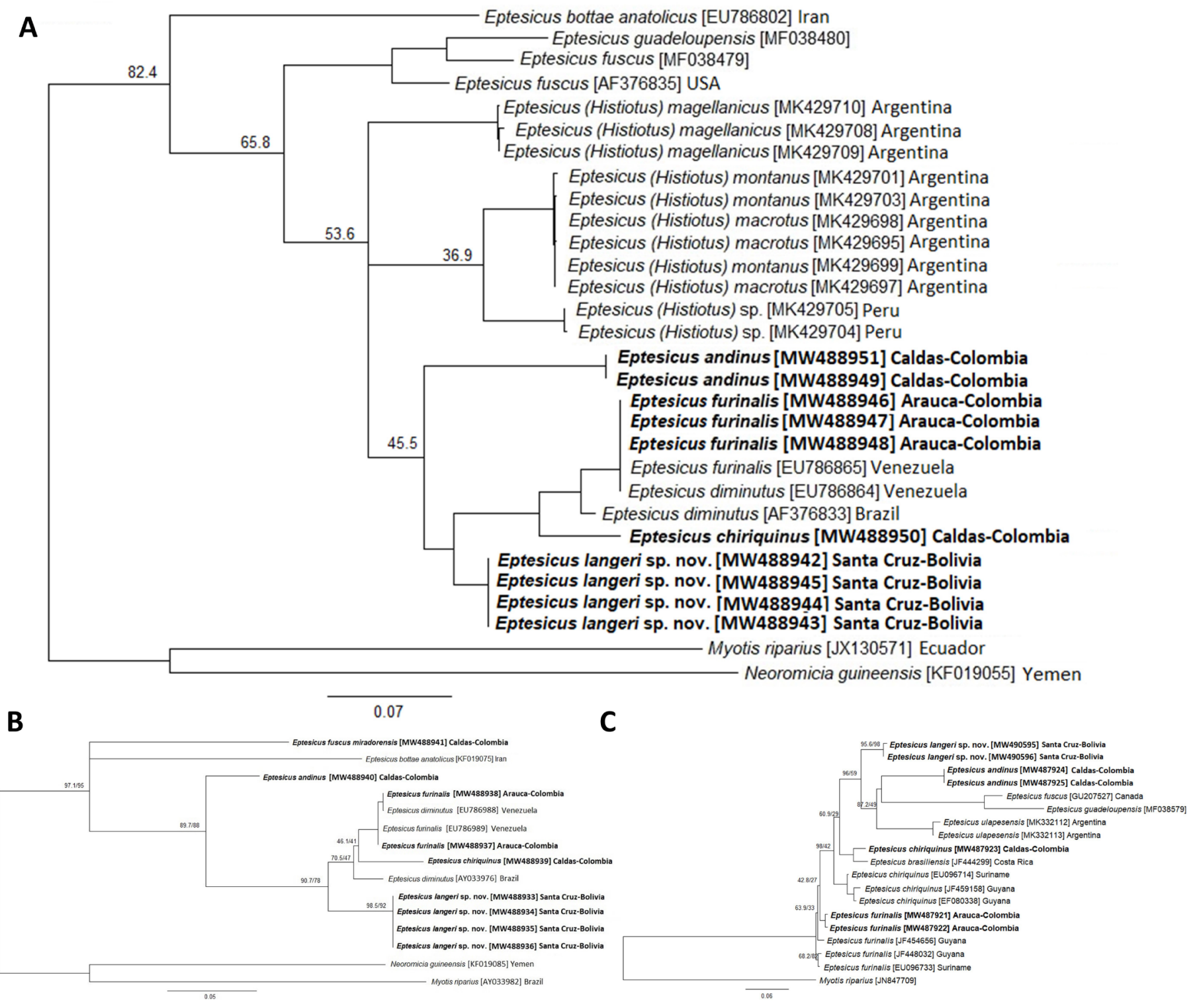




\section{Appendix 2}

Average intraspecific (on the diagonal) and interspecific (below the diagonal) distances based on Kimura two parameters for the mtDNA cytochrome c oxidase subunit I (COI) gene.

\begin{tabular}{|c|c|c|c|c|c|c|c|c|c|c|}
\hline & Species & 1 & 2 & 3 & 4 & 5 & 6 & 7 & 8 & 9 \\
\hline 1 & Eptesicus sp. (Bolivia) & 0.005 & & & & & & & & \\
\hline 2 & E. furinalis & $0.085-0.094$ & $0.006-0.025$ & & & & & & & \\
\hline 3 & E. chiriquinus & $0.077-0.079$ & $0.037-0.067$ & $0.011-0.074$ & & & & & & \\
\hline 4 & E. andinus & $0.097-0.127$ & $0.137-0.168$ & $0.119-0.138$ & 0.000 & & & & & \\
\hline 5 & E. ulapesensis & $0.116-0.129$ & $0.135-0.160$ & $0.129-0.146$ & $0.148-0.154$ & 0.011 & & & & \\
\hline 6 & E. brasiliensis & 0.091 & $0.069-0.071$ & $0.035-0.065$ & $0.124-0.137$ & $0.134-0.140$ & - & & & \\
\hline 7 & E. fuscus & $0.170-0.172$ & $0.169-0.191$ & $0.183-0.202$ & $0.206-0.220$ & $0.188-0.194$ & 0.194 & - & & \\
\hline 8 & E. guadeloupensis & $0.207-0.214$ & $0.178-0.204$ & $0.190-0.215$ & $0.243-0.245$ & $0.212-0.223$ & 0.206 & 0.101 & - & \\
\hline 9 & Myotis riparius & $0.277-0.283$ & $0.258-0.292$ & $0.279-0.304$ & $0.330-0.353$ & $0.304-0.313$ & 0.290 & 0.312 & 0.320 & - \\
\hline
\end{tabular}

\section{Appendix 3}

Morphometric comparison of two cranial variables of Eptesicus andinus from: Bolivia (square), Brazil (inverted triangle), Colombia (X), Ecuador (black and white circle), Peru (triangle) and Venezuela (circle); E. langeri (star), holotype (star full); holotypes from E. andinus (circle full 2), E. chiralensis (circle full 1) and E. montosus (circle full 3).

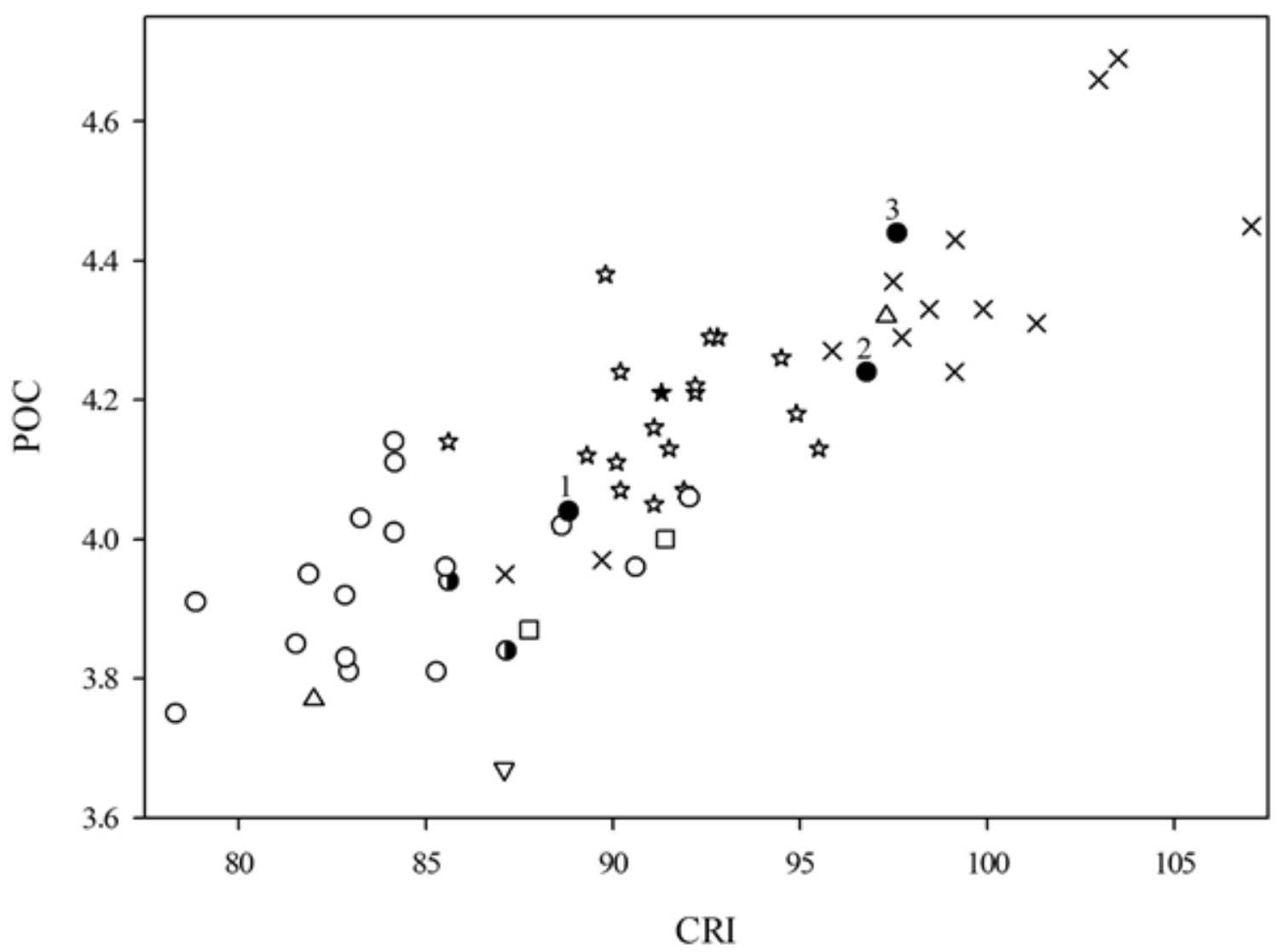




\section{Appendix 4}

Comparison of measurements $(\mathrm{mm})$ of E. langeri with other Neotropical Eptesicus species. Average, minimum and maximum (parentheses), number of specimens examined.

\begin{tabular}{|c|c|c|c|c|c|c|c|c|}
\hline Variable & E. diminutus & E. furinalis & E. andinus & E. langeri sp. nov. & $\begin{array}{c}\text { E. ulapesensis } \\
\text { (Sánchez et al. 2019) }\end{array}$ & E. brasiliensis & E. chiriquinus & $\begin{array}{c}\text { E. taddeii } \\
\text { (Miranda et al. 2006) }\end{array}$ \\
\hline GLS & $\begin{array}{c}13.7(12.5-14.7) \\
10\end{array}$ & $\begin{array}{c}15.2(14.4-16.1) \\
44\end{array}$ & $\begin{array}{c}15.4(14.2-16.7) \\
38\end{array}$ & $\begin{array}{c}15.6(14.8-16.2) \\
19\end{array}$ & 16.5 (15.9-17.0) 9 & $17.0(16.7-17.4) 5$ & $\begin{array}{c}17.0(16.5-17.8) \\
21\end{array}$ & 17.9 (17.3-18.4) 24 \\
\hline $\mathrm{CCL}$ & $\begin{array}{c}12.8(11.9-13.6) \\
10\end{array}$ & $\begin{array}{c}14.1(13.3-14.9) \\
44\end{array}$ & $\begin{array}{c}15.3(14.3-15.9) \\
13\end{array}$ & $\begin{array}{c}14.5(13.7-14.9) \\
19\end{array}$ & $15.8(15.6-16.1) 9$ & $15.8(15.6-16.4) 5$ & $\begin{array}{c}16.0(15.6-16.5) \\
21\end{array}$ & $16.8(16-17.4) 24$ \\
\hline $\mathrm{BL}$ & $\begin{array}{c}11.4(10.2-13.7) \\
10\end{array}$ & $\begin{array}{c}12.7(12.0-13.5) \\
44\end{array}$ & $\begin{array}{c}13.4(12.9-14.1) \\
13\end{array}$ & $\begin{array}{c}13.1(12.6-13.6) \\
19\end{array}$ & - & - & $\begin{array}{c}14.3(13.8-14.8) \\
21\end{array}$ & - \\
\hline PAL & $5.8(5.1-6.4) 10$ & $6.7(6.2-7.1) 44$ & $7.3(6.9-7.5) 13$ & $7.2(6.5-7.7) 19$ & $6.7(6.0-7.6) 6$ & $7.6(7.5-8.0) 5$ & $7.8(6.9-8.8) 21$ & - \\
\hline POC & $3.7(3.4-4.0) 10$ & $3.8(3.5-4.9) 44$ & $4.1(3.7-4.7) 38$ & $4.2(4.0-4.4) 19$ & $3.9(3.8-4.1) 9$ & $4.0(3.8-4.1) 5$ & $4.2(3.8-4.6) 21$ & $4.1(3.9-4.4) 24$ \\
\hline $\mathrm{BCH}$ & $5.1(4.7-6.1) 10$ & $5.7(4.9-6.2) 44$ & $5.9(5.7-6.3) 13$ & $6.4(5.9-6.8) 19$ & - & - & $6.5(5.8-7.6) 21$ & - \\
\hline $\mathrm{BCB}$ & 6.9 (6.5-7.6) 10 & $7.3(6.8-7.7) 44$ & $7.6(7.1-8.4) 38$ & $7.5(7.4-7.7) 19$ & $8.3(8.1-8.6) 9$ & $7.7(7.5-8.1) 5$ & $7.8(6.3-8.3) 21$ & $8.1(7.7-8.5) 24$ \\
\hline MB & $7.4(6.8-8.2) 10$ & $8.3(7.7-9.3) 44$ & $8.3(7.8-8.8) 36$ & $8.4(8.1-8.6) 19$ & $8.8(8.2-9.2) 9$ & $9.1(8.7-9.5) 5$ & $8.9(8.5-9.3) 21$ & - \\
\hline ZB & $9.3(8.6-10.3) 6$ & $10.3(9.7-10.8) 35$ & $\begin{array}{c}10.7(10.1-11.2) \\
12\end{array}$ & $\begin{array}{c}10.7(10.4-11.0) \\
19\end{array}$ & $11.1(10.6-11.6) 9$ & $12.0(12.0-12.1) 2$ & $11.5(10.7-12.0)$ & $12.2(11.7-12.9)$ \\
\hline IOB & $4.6(4.1-4.9) 10$ & $4.9(3.8-5.5) 44$ & $5.4(4.9-5.8) 13$ & $5.2(4.9-5.4) 19$ & - & $6.4(5.9-7.2) 5$ & $5.8(5.4-6.4) 21$ & - \\
\hline $\mathrm{C}-\mathrm{C}$ & $4.3(3.9-4.7) 10$ & $4.8(4.3-5.1) 44$ & $5.1(4.6-5.4) 13$ & $4.9(4.7-5.3) 19$ & $5.1(4.8-5.4) 9$ & $5.5(5.3-5.7) 5$ & $5.3(4.9-5.6) 21$ & $5.7(5.5-6.1) 24$ \\
\hline M3-M3 & $6.1(5.5-6.6) 10$ & $6.7(6.0-6.9) 44$ & $6.7(6.3-7.4) 38$ & $6.9(6.4-7.2) 19$ & $6.7(6.2-7.2) 9$ & $7.3(7.1-7.6) 5$ & $7.4(7.0-7.8) 21$ & $7.5(7.0-7.8) 24$ \\
\hline $\mathrm{C}-\mathrm{M3}$ & $4.9(4.6-5.4) 10$ & $5.7(5.1-6.0) 44$ & $5.9(5.5-6.2) 38$ & $6.0(5.8-6.3) 19$ & $6.2(5.9-6.5) 9$ & $6.4(6.2-6.7) 5$ & $6.6(6.4-6.9) 21$ & $6.8(6.4-7.1) 24$ \\
\hline I-M3 & $5.8(5.4-6.2) 10$ & $6.5(6.2-6.8) 44$ & $6.9(6.7-7.3) 13$ & $6.8(6.6-7.0) 19$ & - & - & $7.6(7.2-8.1) 21$ & - \\
\hline$c-m 3$ & $5.4(5.0-5.8) 10$ & $6.2(5.5-6.5) 44$ & $6.6(6.4-6.8) 13$ & $6.4(6.3-6.8) 19$ & $6.8(6.4-7.3) 9$ & $6.8(6.7-7.0) 5$ & $7.2(6.9-7.5) 21$ & $7.3(7.1-7.7) 24$ \\
\hline P-M3 & $3.9(3.6-4.2) 10$ & $4.5(4.1-4.9) 44$ & $4.8(4.6-5.1) 13$ & $4.8(4.6-5.0) 19$ & - & - & $5.2(4.3-5.6) 21$ & - \\
\hline$p-m 3$ & $4.7(4.3-5.2) 7$ & $5.5(5.2-6.2) 44$ & $5.7(5.4-5.9) 13$ & $5.6(5.4-5.9) 19$ & - & - & $6.2(5.7-6.6) 21$ & - \\
\hline MAL & $\begin{array}{c}10.1(9.5-11.0) \\
10\end{array}$ & $\begin{array}{c}11.7(11.0-12.4) \\
44\end{array}$ & $\begin{array}{c}12.5(11.3-13.0) \\
13\end{array}$ & $\begin{array}{c}12.1(11.2-12.6) \\
19\end{array}$ & $12.2(11.8-12.8) 9$ & $13.1(12.9-13.5) 5$ & $\begin{array}{c}13.7(13.1-14.4) \\
21\end{array}$ & 13.5 (13.0-13.7) 24 \\
\hline $\mathrm{MH}$ & 3.9 (3.4-4.6) 10 & $4.6(4.1-5.2) 44$ & $4.6(4.2-5.2) 13$ & $4.5(4.2-4.8) 19$ & - & - & $5.2(4.9-5.7) 21$ & - \\
\hline LT & $84.8(80-91) 8$ & 95.4 (84-107) 38 & $97.1(83-116) 35$ & $96.4(90-106) 19$ & $103.6(93-115) 9$ & $108.8(101-117) 6$ & $104.6(92-114) 17$ & $108.6(99-117) 24$ \\
\hline TL & $34.6(27-39) 8$ & $40.7(35-48) 38$ & $40.2(31-52) 35$ & $42.1(39-46) 19$ & $44.7(36-49) 9$ & $43.8(37-49) 6$ & $43.4(36-48) 21$ & $47.9(43-53) 24$ \\
\hline $\mathrm{EL}$ & $13.4(12-15) 7$ & $14.6(10-19) 38$ & $14.6(8-19) 30$ & $14.8(12.5-17) 19$ & $15.3(13-19) 9$ & $16.8(16-18) 6$ & $14.2(10-17) 21$ & $15.6(14-17) 24$ \\
\hline LF & $7.8(7-10) 8$ & $8.6(7-10) 38$ & $9.7(7-13) 37$ & $8.6(7-10) 19$ & $8.6(7-10) 9$ & $9.1(8-11) 6$ & $\begin{array}{c}10.3(8.6-11.24) \\
21\end{array}$ & - \\
\hline Weight & $6.3(5-7.5) 4$ & $8.0(5-11.5) 36$ & $9.7(7-13) 13$ & $9.6(8-12) 17$ & $10.7(9-14) 9$ & $5.9(4.9-6.5) 5$ & $11.6(10-14) 14$ & - \\
\hline PD & $6.3(5-8) 3$ & $6.8(6-8) 13$ & $9.5(8-12) 12$ & $7.7(6-9.5) 16$ & $\sim 6$ & - & $9.3(7-11) 18$ & $\sim 7$ \\
\hline PV & (7) 1 & $6.1(5-7) 13$ & $7.9(7-9) 12$ & $6.8(6-8) 14$ & - & - & 7.7 (7-9) 17 & - \\
\hline FA & $\begin{array}{c}33.8(31.2-35.9) \\
9\end{array}$ & $\begin{array}{c}40.1(36.4-43.4) \\
44\end{array}$ & $\begin{array}{c}41.4(37.2-47.0) \\
38\end{array}$ & $\begin{array}{c}42.2(40.1-44.1) \\
19\end{array}$ & $42.8(41.0-44.6) 9$ & $42.0(40.5-45.0) 5$ & $\begin{array}{c}45.9(43.6-47.6) \\
21\end{array}$ & 46.5 (44.1-48.7) 24 \\
\hline CRI & $73.1(62-83) 10$ & $84.1(76-92) 44$ & 90.3 (78-107) 38 & $91.3(86-96) 19$ & 100.9 (98-106) 9 & - & $116(92-108) 21$ & - \\
\hline MXI & 25.9 (22-29) 10 & $32.1(27-36) 44$ & 36.3 (33-39) 13 & $35.5(33-39) 19$ & $36.5(34-41) 9$ & - & $41.9(40-45) 21$ & $44.8(41-49) 24$ \\
\hline
\end{tabular}




\section{Appendix 5}

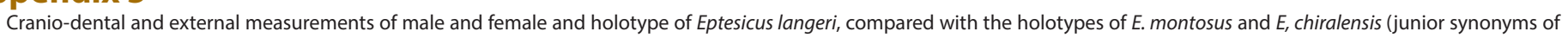
E. andinus), and E. andinus.

\begin{tabular}{|c|c|c|c|c|c|c|}
\hline Variables & $\begin{array}{c}\text { montosus } \\
\text { BMNH } \\
\text { 2.1.1.1 } \\
\text { Bolivia }\end{array}$ & $\begin{array}{c}\text { chiralensis } \\
\text { AMNH } \\
47219 \\
\text { Ecuador }\end{array}$ & $\begin{array}{c}\text { andinus } \\
\text { AMNH } \\
33807 \\
\text { Colombia }\end{array}$ & $\begin{array}{c}\text { langeri } \\
\text { MNKM } \\
5584 \\
\text { Bolivia }\end{array}$ & $\begin{array}{c}\begin{array}{c}\text { Iangeri } \\
n=7\end{array} \\
\text { Bolivia }\end{array}$ & $\begin{array}{l}\text { langeri } \\
\mathrm{n}=12 \\
\text { Bolivia }\end{array}$ \\
\hline Sex & Male & Male & Male & Female & Male & Female \\
\hline GLS & 15.79 & 15.22 & 16.01 & 15.44 & $14.75-15.98$ & $15.26-16.15$ \\
\hline $\mathrm{CCL}$ & 14.80 & 14.68 & 15.13 & 14.64 & $13.77-14.78$ & $14.29-14.93$ \\
\hline$B L$ & 12.73 & 12.6 & 13.47 & 12.69 & $12.55-13.27$ & $12.69-13.57$ \\
\hline PAL & 6.92 & 6.66 & 6.87 & 7.09 & $6.85-7.37$ & $6.51-7.69$ \\
\hline POC & 4.44 & 4.04 & 4.24 & 4.21 & $4.05-4.38$ & $4.02-4.29$ \\
\hline $\mathrm{BCH}$ & 5.97 & 6.00 & 5.98 & 6.43 & $6.30-6.63$ & $5.95-6.83$ \\
\hline $\mathrm{BCB}$ & 7.92 & 7.63 & 7.85 & 7.62 & $7.43-7.70$ & $7.43-7.70$ \\
\hline MB & 8.64 & 8.10 & 8.40 & 8.39 & $8.06-8.48$ & $8.13-8.64$ \\
\hline ZB & 10.35 & 10.34 & 10.55 & 10.68 & $10.35-10.86$ & $10.49-11$ \\
\hline $\mathrm{IOB}$ & 5.23 & 5.15 & 5.30 & 5.24 & $4.92-5.30$ & 4.97-5.39 \\
\hline$C-C$ & 5.14 & 4.94 & 5.28 & 5.33 & $4.67-5.03$ & 4.83-5.33 \\
\hline M3-M3 & 6.76 & 6.69 & 6.62 & 7.07 & $6.37-6.92$ & $6.73-7.15$ \\
\hline C-M3 & 5.94 & 5.83 & 6.07 & 6.08 & $5.86-6.15$ & $5.83-6.30$ \\
\hline I-M3 & 6.76 & 6.47 & 6.74 & 6.72 & $6.59-6.93$ & $6.68-7.01$ \\
\hline$c-m 3$ & 6.30 & 6.26 & 6.40 & 6.41 & $6.25-6.53$ & $6.26-6.75$ \\
\hline P-M3 & 4.50 & 4.48 & 4.81 & 4.76 & $4.67-4.94$ & $4.6-5.04$ \\
\hline$p-m 3$ & - & 5.05 & 5.67 & 5.54 & $5.42-5.73$ & $5.39-5.92$ \\
\hline MAL & 10.90 & 11.49 & 12.21 & 12.39 & $11.16-12.32$ & $11.64-12.6$ \\
\hline $\mathrm{MH}$ & - & 4.44 & 4.49 & 4.77 & $4.22-4.84$ & $4.29-4.77$ \\
\hline LT & 98.00 & 97.00 & 100 & 94 & $\begin{array}{l}90.00- \\
106.00\end{array}$ & $\begin{array}{l}90.00- \\
100.00\end{array}$ \\
\hline TAIL & 43.00 & 38.00 & 35.00 & 42.5 & $38.50-43.00$ & $40.00-46.00$ \\
\hline EAR & 18.00 & - & - & 16.5 & $12.50-15.60$ & $13.00-17.00$ \\
\hline $\mathrm{HF}$ & 10.04 & 10.00 & 8.00 & 9 & $7.00-9.00$ & $7.00-10.00$ \\
\hline FA & 42.79 & 41.10 & 43.60 & 43.02 & $40.09-43.11$ & $40.64-44.10$ \\
\hline PD & 9.00 & 7.00 & 9.00 & 7 & $8.00-10.00$ & $6.00-10.00$ \\
\hline PV & - & 7.00 & 8.00 & 5 & $6.00-8.00$ & $5.00-7.00$ \\
\hline CRI & 97.60 & 88.80 & 96.80 & 91.3 & $85.60-94.90$ & $88.60-95.50$ \\
\hline MXI & 35.30 & 33.90 & 36.10 & 37.7 & $32.60-36.40$ & $34.20-38.40$ \\
\hline
\end{tabular}




\section{Appendix 6}

Morphometry of E. langeri sp. nov. from Bolivia, * holotype.

\begin{tabular}{|c|c|c|c|c|c|c|c|c|c|c|c|c|c|c|c|c|c|c|c|}
\hline Sex & $\begin{array}{l}\text { MNKM } \\
5584^{*} \\
\text { female }\end{array}$ & $\begin{array}{c}\text { MNKM } \\
5117 \\
\text { female }\end{array}$ & $\begin{array}{c}\text { MNKM } \\
5585 \\
\text { female }\end{array}$ & $\begin{array}{c}\text { MNKM } \\
4436 \\
\text { female }\end{array}$ & $\begin{array}{c}\text { MNKM } \\
5586 \\
\text { female }\end{array}$ & $\begin{array}{c}\text { MNKM } \\
5587 \\
\text { female }\end{array}$ & $\begin{array}{c}\text { MNKM } \\
5588 \\
\text { female }\end{array}$ & $\begin{array}{c}\text { MNKM } \\
5589 \\
\text { female }\end{array}$ & $\begin{array}{c}\text { MNKM } \\
5676 \\
\text { female }\end{array}$ & $\begin{array}{c}\text { MNKM } \\
5636 \\
\text { female }\end{array}$ & $\begin{array}{c}\text { MNKM } \\
5088 \\
\text { female }\end{array}$ & $\begin{array}{c}\text { MNKM } \\
5697 \\
\text { female }\end{array}$ & $\begin{array}{c}\text { MNKM } \\
4679 \\
\text { male }\end{array}$ & $\begin{array}{c}\text { MNKM } \\
5592 \\
\text { male }\end{array}$ & $\begin{array}{c}\text { MNKM } \\
5126 \\
\text { male }\end{array}$ & $\begin{array}{c}\text { MNKM } \\
4678 \\
\text { male }\end{array}$ & $\begin{array}{c}\text { MNKM } \\
5692 \\
\text { male }\end{array}$ & $\begin{array}{c}\text { MNKM } \\
5590 \\
\text { male }\end{array}$ & $\begin{array}{l}\text { MNKM } \\
5591 \\
\text { male }\end{array}$ \\
\hline GLS & 15.44 & 15.79 & 15.39 & 15.48 & 15.26 & 15.64 & 15.45 & 16.15 & 15.40 & 15.74 & 15.58 & 16.02 & 15.09 & 15.76 & 14.75 & 15.80 & 15.77 & 15.70 & 15.98 \\
\hline $\mathrm{CCL}$ & 14.64 & 14.88 & 14.41 & 14.53 & 14.29 & 14.51 & 14.46 & 14.93 & 14.30 & 14.38 & 14.60 & 14.80 & 13.90 & 14.78 & 13.77 & 14.57 & 14.50 & 14.44 & 14.75 \\
\hline $\mathrm{BL}$ & 12.69 & 13.46 & 12.80 & 13.27 & 13.07 & 12.98 & 12.83 & 13.57 & 13.15 & 13.33 & 13.14 & 13.24 & 12.55 & 13.12 & 13.13 & 13.27 & 12.88 & 13.2 & 12.73 \\
\hline PAL & 7.09 & 7.69 & 6.51 & 7.38 & 6.99 & 7.36 & 7.01 & 7.43 & 6.93 & 7.29 & 7.06 & 7.34 & 6.87 & 7.22 & 6.85 & 7.36 & 7.16 & 7.37 & 7.10 \\
\hline POC & 4.21 & 4.13 & 4.12 & 4.02 & 4.24 & 4.16 & 4.07 & 4.13 & 4.11 & 4.21 & 4.29 & 4.26 & 4.38 & 4.07 & 4.14 & 4.29 & 4.05 & 4.22 & 4.18 \\
\hline $\mathrm{BCH}$ & 6.43 & 6.44 & 6.38 & 6.33 & 6.30 & 6.39 & 6.19 & 6.83 & 5.95 & 6.32 & 6.20 & 6.68 & 6.40 & 6.63 & 6.35 & 6.40 & 6.44 & 6.30 & 6.49 \\
\hline$B C B$ & 7.62 & 7.46 & 7.49 & 7.43 & 7.58 & 7.49 & 7.61 & 7.70 & 7.59 & 7.50 & 7.62 & 7.54 & 7.52 & 7.59 & 7.47 & 7.43 & 7.50 & 7.52 & 7.70 \\
\hline $\mathrm{MB}$ & 8.39 & 8.22 & 8.13 & 8.44 & 8.43 & 8.35 & 8.34 & 8.64 & 8.37 & 8.62 & 8.60 & 8.29 & 8.27 & 8.48 & 8.40 & 8.38 & 8.17 & 8.06 & 8.31 \\
\hline ZB & 10.68 & 10.49 & 10.69 & 10.59 & 10.58 & 10.69 & 10.62 & 11.00 & 10.73 & 10.72 & 10.76 & 10.69 & 10.86 & 10.85 & 10.53 & 10.84 & 10.35 & 10.39 & 10.66 \\
\hline IOB & 5.24 & 5.16 & 5.18 & 4.97 & 5.19 & 5.02 & 5.23 & 5.19 & 5.19 & 5.05 & 5.37 & 5.39 & 4.93 & 5.14 & 5.14 & 5.25 & 4.92 & 5.17 & 5.30 \\
\hline$C-C$ & 5.33 & 4.85 & 4.83 & 4.96 & 4.93 & 4.99 & 5.04 & 4.94 & 5.06 & 4.97 & 4.88 & 5.22 & 4.71 & 5.03 & 4.67 & 4.96 & 4.75 & 4.92 & 5.03 \\
\hline M3-M3 & 7.07 & 7.10 & 6.74 & 6.74 & 6.78 & 6.80 & 6.90 & 6.84 & 6.92 & 6.73 & 6.99 & 7.15 & 6.75 & 6.84 & 6.78 & 6.87 & 6.37 & 6.92 & 6.87 \\
\hline C-M3 & 6.08 & 6.30 & 5.92 & 6.09 & 6.03 & 6.07 & 5.83 & 5.96 & 5.99 & 5.99 & 5.89 & 6.22 & 5.90 & 6.09 & 5.86 & 6.12 & 5.88 & 6.15 & 6.03 \\
\hline I-M3 & 6.72 & 7.01 & 6.80 & 6.98 & 6.77 & 6.68 & 6.71 & 6.76 & 6.77 & 6.83 & 6.71 & 6.97 & 6.63 & 6.85 & 6.59 & 6.93 & 6.70 & 6.86 & 6.84 \\
\hline$c-m 3$ & 6.41 & 6.66 & 6.29 & 6.63 & 6.37 & 6.41 & 6.26 & 6.50 & 6.47 & 6.44 & 6.51 & 6.75 & 6.38 & 6.34 & 6.25 & 6.53 & 6.45 & 6.39 & 6.42 \\
\hline P-M3 & 4.76 & 4.69 & 4.77 & 4.83 & 4.66 & 4.72 & 4.63 & 4.67 & 4.60 & 4.66 & 4.82 & 5.04 & 4.67 & 4.93 & 4.79 & 4.82 & 4.84 & 4.87 & 4.94 \\
\hline$p-m 3$ & 5.54 & 5.88 & 5.62 & 5.64 & 5.59 & 5.92 & 5.39 & 5.65 & 5.49 & 5.58 & 5.48 & 5.85 & 5.46 & 5.72 & 5.42 & 5.73 & 5.53 & 5.59 & 5.73 \\
\hline MAL & 12.39 & 12.60 & 12.26 & 12.54 & 12.45 & 12.48 & 12.15 & 12.13 & 11.64 & 11.70 & 11.97 & 11.98 & 11.16 & 12.32 & 11.87 & 11.90 & 11.44 & 12.23 & 12.30 \\
\hline $\mathrm{MH}$ & 4.77 & 4.57 & 4.69 & 4.75 & 4.49 & 4.72 & 4.40 & 4.72 & 4.29 & 4.34 & 4.5 & 4.46 & 4.38 & 4.37 & 4.22 & 4.84 & 4.46 & 4.36 & 4.47 \\
\hline LT & 94 & 100 & 98 & 97 & 95 & 96 & 97 & 100 & 90 & 92 & 94.5 & 97 & 90 & 106 & 97 & 98.5 & 90 & 100 & 100 \\
\hline $\mathrm{TL}$ & 42.5 & 40 & 43 & 43 & 46 & 44.5 & 44.5 & 44 & 38.5 & 40.5 & 41 & 44 & 38.5 & 43 & 39 & 41 & 41 & 40 & 40 \\
\hline $\mathrm{EL}$ & 16.5 & 14 & 16 & 13.5 & 13 & 17 & 15 & 13.5 & 14 & 14 & 15.5 & 15 & 15 & 15 & 12.5 & 15.6 & 15.5 & 15 & 14 \\
\hline $\mathrm{HF}$ & 9 & 10 & 8 & 10 & 8.5 & 10 & 8 & 9.5 & 8 & 9 & 7 & 8 & 9 & 8 & 8.5 & 9 & 8.5 & 9 & 7 \\
\hline FA & 43.02 & 41.52 & 41.54 & 42.95 & 43.2 & 43.25 & 43.76 & 44.1 & 41.15 & 43.35 & 40.64 & 42.77 & 41.58 & 41.85 & 42.66 & 43.11 & 41.15 & 40.09 & 40.54 \\
\hline PD & 7 & - & 7 & 7 & 6 & 10 & 8 & - & 7 & 7 & 8 & - & 10 & 8 & 9 & 9 & 10 & 8 & 8 \\
\hline PV & 5 & - & 6 & 6 & 6 & 7 & 6 & - & - & - & 6 & - & 7 & 7 & 7 & 8 & 8 & 6 & 7 \\
\hline CRI & 91.30 & 91.50 & 89.30 & 88.60 & 90.20 & 91.10 & 90.20 & 95.50 & 90.10 & 92.20 & 92.80 & 94.50 & 89.80 & 91.90 & 85.60 & 92.60 & 91.10 & 92.20 & 94.90 \\
\hline MXI & 37.70 & 37.60 & 34.20 & 35.60 & 35.30 & 35.70 & 34.80 & 35.10 & 35.90 & 35.00 & 34.90 & 38.40 & 33.80 & 36.10 & 33.50 & 36.20 & 32.60 & 36.40 & 35.90 \\
\hline
\end{tabular}




\section{Appendix 7}

GenBank accession numbers for sequences generated in this study are indicated in boldface type; all others were published previously. Cyt- $b=$ cytochrome b; ND1 = nicotinamide adenine dinucleotide dehydrogenase; $C O I=$ cytochrome oxidase subunit I.

\begin{tabular}{|c|c|c|c|}
\hline Taxon & Cyt-b & ND1 & COI \\
\hline Eptesicus andinus & MW488951, MW488949 & MW488940 & MW487924, MW487925 \\
\hline Eptesicus brasiliensis & & & JF444299 \\
\hline Eptesicus bottae anatolicus & EU786802 & KF019075 & \\
\hline Eptesicus chiriquinus & MW488950 & MW488939 & JF459158, EU096714, EF080338, MW487923 \\
\hline Eptesicus diminutus & EU786864, AF376833 & EU786988, AY033976 & \\
\hline Eptesicus furinalis & EU786865, MW488946-MW488948 & EU786989, MW488937, MW488938 & $\begin{array}{l}\text { EU096733, JF448032, JF454656, MW487921, } \\
\text { MW487922 }\end{array}$ \\
\hline Eptesicus fuscus & AF376835, MF038479 & & GU207527 \\
\hline Eptesicus fuscus miradorensis & & MW488941 & \\
\hline Eptesicus guadeloupensis & MF038480 & & MF038579 \\
\hline Eptesicus langeri & MW488942-MW488945 & MW488933-MW488936 & MW490595; MW490596 \\
\hline Eptesicus ulapesensis & & & МK332112, МK332113 \\
\hline Eptesicus (Histiotus) montanus & MK429701, MK429703, MK429699 & & \\
\hline $\begin{array}{l}\text { Eptesicus (Histiotus) magel- } \\
\text { lanicus }\end{array}$ & MK429710, MK429709, MK429708 & & \\
\hline Eptesicus (Histiotus) macrotus & MK429698, MK429697, MK429695 & & \\
\hline Eptesicus (Histiotus) sp. & MK429705, MK429704 & & \\
\hline Myotis riparius & JX130571 & AY033982 & JN847709 \\
\hline Neoromicia guineensis & KF019055 & KF019085 & \\
\hline
\end{tabular}




\section{Appendix 8}

Revised Specimens:

Eptesicus andinus ( $n=39$ ). BOLIVIA. Beni: Lago LargoComunidad Maravilla (MNKM 5598). Cochabamba: Corani (AMNH 268653). Choro (BMNH 2.1.1.1 "Holotype E. montosus"). La Paz: PN ANMI Madidi (MNKM 5599). BRASIL. Goiás (AMNH 134910). COLOMBIA. Cauca: Município de Páez (Belalcázar); Parque Nacional Natural, (P.N.N.) Nevado del Huila, Irlanda, Estación Inderena, 2800 m (ICN 763740). Caldas: Aranzazu, vereda El Diamante, 3420 m (MHNUCa-M 2633-2634). Huila: Valle de las Papas (AMNH 33807 "Holotype E. andinus"). Quindío: municipio de Salento; 3250 m (UV 3358-59). Reserva Natural Cañón Quindío, frente de reforestación "La Montaña", 2900 m (ICN 12449). Frente de reforestación "La Romelia", 2630 m, (ICN 12450). Frente de reforestación "La Picota", 2730 m (ICN 12451-2). El Roble (AMNH 32802). Risaralda: Pereira, vereda La Pastora, Parque Regional Natural Ucumarí, 2470 m (ICN 11270). ECUADOR. El Oro: El Chiral (AMNH 47218, 47219“Holotype E. chiralensis", 47220). PERÚ. Chanchamayo (BMNH 76152). Junín, Tarma, San Ramón (AMNH 23780). Cuzco, Pillahuata (FMNH 123953). VENEZUELA. Caracas: Los Venados (USNM 370935-37, 370943-44, 370949-53, 370955, 370962-63). Maracaibo: Falcon Cerro Sapoco (USNM 441764). Montalbán: La Copa (USNM 441755).

Eptesicus brasiliensis $(n=4)$. ARGENTINA. Corrientes, Goya (BMNH 98345, 98346). BOLIVIA. Santa Cruz: Comarapa (AMNH 260257). COLOMBIA. Meta (UV 7725). ECUADOR. Oriente, Canelos (BMNH 54373).

Eptesicus chiriquinus $(n=21)$. COLOMBIA. Quindío: municipio Finlandia; vereda El Roble, Reserva Forestal Bremen-La Popa, 1950 m, (ICN 12483). Antioquia: San Luis; San Pablo, quebrada San Antonio, 810 m (ICN 9881-82). Yarumal; El Cedro, Media Luna (CTUA 11083). El Cedro, El Sombrero (CTUA 10965). Cauca (JVS-254, 269, MHNUC 1497); municipio de Cajibío: vereda El Cofre, finca La Herencia 1700 m (UV 13178). Cundinamarca: municipio de Paime, vereda El Carmen, Inspección de Policía Cuatro Caminos, 1400 m (MUD 116, 125, 138, 139). Santander: municipio Los Santos, vereda Mesitas de San Javier, bosque de Los Alpes, $1550 \mathrm{~m}$ (ICN 16653). Encino, Vereda Río Negro, sitio Cachalú, finca La Desdichada, 2000 m (ICN 17623). Valle Del Cauca: municipio La Victoria; hacienda El Chaquiral (UV 4055). Pance: río Pance, estación Pueblo Pance 1460 m (UV 3551, 3889, 4363). Municipio El Cairo, Estación Cerro del Inglés 2000 m (UV 13094). Valle Del Cauca: Buenaventura; vía BuenaventuraZaragoza, 180 m (MHNUC, colector number HERC-502).

Eptesicus diminutus $(n=7)$. ARGENTINA. Río Negro, Balneario Las Cañas (CML 1859). Buenos Aires: Delta, Canal 6 y P. Palmas (CML 1820). Jujuy: Laguna La Brea $25 \mathrm{~km}$ al W de Palma Sola (CML 3086). Salta Dept. General San Martin; $11 \mathrm{~km}$ intersección ruta 34 camino a Acambuco, (CML 6139). Anta Arroyo La Sala Centro Administrativo Parque Nacional El Rey (CML 6050). Corrientes (BMNH 24664). Santa Fe, Esperanza (BMNH 1241). BOLÍVIA. SANTA CRUZ, Ñuflo de
Chávez (MNKM 4527). Florida (MNKM 5658). PARAGUAY. Villa Rica (BMNH 1811).

Eptesicus furinalis ( $n=56)$. ARGENTINA. Chaco: Almirante Brown (CML 3220, 3221, 3225, 3226, 3850, 3854). Güemes (CML 5397). Córdoba: Cruz del Eje (BMNH 2251). Corrientes: Ituzaingó, San Borgita (BMNH 691246). Formosa: Bermejo (CML 3855-56). Pilcomayo (CML 4670); Rio Bermejo (CML 5311). Estero Poi, Pto. Algarrobo (CML 4572). Jujuy: Laguna La Brea (CML 3085). Doctor Manuel Belgrano (CML 4312-13). Rio Ledesma (CML 5223). Rio de Sora (CML 5224). La Rioja: San Blas de los Sauces (CML5445). Misiones: Guaraní (CML 3857). Salta: Piquirenda Viejo (CML 5220, 522). Rio Itiyuro (CML 5372). Oran: Santa María (CML 5221), Oran (CML 4331, 5142-45). Tucumán: Arroyo Aguas Chiquitas (CML 5225-27), Concepción (BMNH 25311). Rio chico: Reserva Provincial Santa Ana (CML 5430). BOLIVIA. Beni: Reserva de la Paraba Barba Azul (MNKM 4982). Santa Cruz: Parque Kaa lya, Cerro Cortado (MNKM 3440). Agua Rica (MNKM 4677-5692). Lajas (MNKM 4999). Pampa Grande (MNKM 5594). Buena Vista (BMNH 2612421). Estancia San Miguelito (MNKM 4546-47). San José de Chiquitos TCO Turubó Este (MNKM 4957-58-59). San Miguel (MNKM 488847). Parque Noel Kempff Mercado (MNKM 5565-95-96). Tarija: Parque Aguaragüe (MNKM 5597). COLOMBIA. Cundinamarca: Bogotá, Santa Fe De Bogotá (BMNH 711368). Cueva del Ermitaño (BMNH 991142). Tolima: Santana, Near Honda (BMNH 109238). Valle Del Cauca: Villa Carmelo (ICN 6298). Risaralda: Pueblo Rico, camino a la bocatoma (ICN 11519). GUYANA. Georgetown: Demerara (BMNH 51111).

Eptesicus langeri sp. nov. $(n=19)$. BOLIVIA. Santa Cruz: Agua Rica (MNKM 5584 holotype, MNKM 5117, 5585, 4436, 5587, 5588, 5088, 5590, 5591, 4679, 5592, 5126, 4678, 5692 paratypes). Agua Clarita (MNKM 5586, 5589, 5676, 5636 paratypes). Reserva Municipal El Chape (MNKM 5697 paratype). 


\section{Appendix 9}

Comparison of diagnostic traits among six species of the genus Eptesicus.

\begin{tabular}{|c|c|c|c|c|c|c|}
\hline Characters & E. furinalis & E. andinus & E. langeri sp. nov. & E. chiriquinus & E. brasiliensis & E. ulapesensis \\
\hline Sagittal and nuchal crests & Joined & Separated & Separated & Joined & Joined & Joined \\
\hline $\begin{array}{l}\text { Development of sagittal } \\
\text { and nuchal crests }\end{array}$ & Developed & Poorly developed & Developed & Well developed & Well developed & Well developed \\
\hline Dorsal coloration & Dark or pale brown & Dark brown & Dark brown & Dark brown - oily black & Dark brown & Yellowish-brown \\
\hline Dorsal fur length & $<7 \mathrm{~mm}$ & $\sim 9 \mathrm{~mm}$ & $\sim 8 \mathrm{~mm}$ & $>8 \mathrm{~mm}$ & $<9 \mathrm{~mm}$ & $\sim 6 \mathrm{~mm}$ \\
\hline Bands of dorsal hair & $\begin{array}{l}\text { Base almost black, tips } \\
\text { light Brown, can change } \\
\text { geographically }\end{array}$ & $\begin{array}{l}\text { Dark Brown with } \\
\text { lighter tips }\end{array}$ & $\begin{array}{l}\text { Slightly bi-colored, dark } \\
\text { base with lighter tips }\end{array}$ & Blackish, homogeneous & $\begin{array}{l}\text { Base dark Brown with } \\
\text { lighter tips }\end{array}$ & $\begin{array}{l}\text { Base dark brown with tips } \\
\text { brownish or goldish- } \\
\text { yellowish }\end{array}$ \\
\hline Bands of ventral hair & $\begin{array}{l}\text { Base dark Brown, almost } \\
\text { black, with yellowish tips }\end{array}$ & $\begin{array}{l}\text { Strongly bi-colored, } \\
\text { base dark and lighter } \\
\text { tips "tanny color" }\end{array}$ & $\begin{array}{l}\text { Base dark with lighter } \\
\text { tips }\end{array}$ & $\begin{array}{l}\text { Base dark Brown with } \\
\text { lighter tips }\end{array}$ & $\begin{array}{l}\text { Base dark Brown with } \\
\text { paler tips (yellowish) }\end{array}$ & $\begin{array}{l}\text { Base dark Brown with whit- } \\
\text { ish tips }\end{array}$ \\
\hline Preorbital process & Poorly developed & Poorly developed & Well developed & Moderately developed & Poorly developed & Poorly developed \\
\hline Braincase & Straight and flattened & Enlarged and rounded & Elevated and rounded & $\begin{array}{l}\text { High and developed } \\
\text { due to the presence of } \\
\text { cranial crests }\end{array}$ & Straight and flattened & Domed \\
\hline Rostrum & Flattened and robust & Delicate and slender & Robust and inflated & Delicate and slender & Robust and inflated & $\begin{array}{l}\text { Slightly flattened and } \\
\text { robust }\end{array}$ \\
\hline
\end{tabular}


